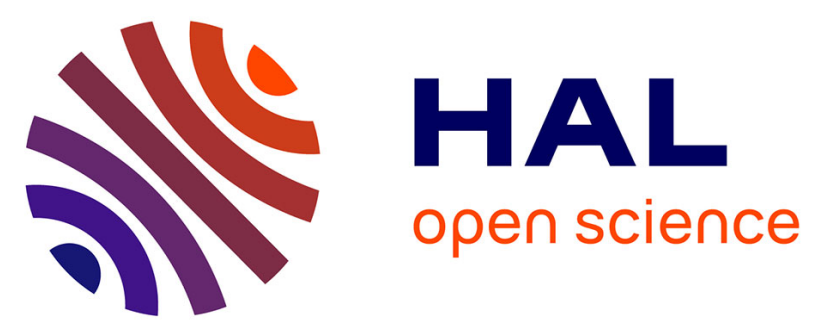

\title{
Integrative taxonomy helps separate four species of freshwater shrimps commonly overlooked as Caridina longirostris (Crustacea: Decapoda: Atyidae) on Indo-West Pacific islands
}

Valentin de Mazancourt, Werner Klotz, Gérard Marquet, Philippe Keith

\section{To cite this version:}

Valentin de Mazancourt, Werner Klotz, Gérard Marquet, Philippe Keith. Integrative taxonomy helps separate four species of freshwater shrimps commonly overlooked as Caridina longirostris (Crustacea: Decapoda: Atyidae) on Indo-West Pacific islands. Invertebrate Systematics, 2018, 32 (6), pp.14221447. 10.1071/IS18034. hal-02171177

\section{HAL Id: hal-02171177 \\ https://hal.science/hal-02171177}

Submitted on 2 Jul 2019

HAL is a multi-disciplinary open access archive for the deposit and dissemination of scientific research documents, whether they are published or not. The documents may come from teaching and research institutions in France or abroad, or from public or private research centers.
L'archive ouverte pluridisciplinaire HAL, est destinée au dépôt et à la diffusion de documents scientifiques de niveau recherche, publiés ou non, émanant des établissements d'enseignement et de recherche français ou étrangers, des laboratoires publics ou privés. 
IS18034

Caridina longirostris and allied species

V. de Mazancourt et al.

\section{Integrative taxonomy helps separate four species of freshwater shrimps commonly overlooked as Caridina longirostris (Crustacea : Decapoda : Atyidae) on Indo-West Pacific islands}

Valentin de Mazancourt ${ }^{\mathrm{A}, \mathrm{C}}$, Werner Klotz ${ }^{\mathrm{B}}$, Gérard Marquet ${ }^{\mathrm{A}}$ and Philippe Keith ${ }^{\mathrm{A}}$

${ }^{\mathrm{A}}$ Muséum national d'Histoire naturelle, Département Adaptations du Vivant, UMR 7208, CP026, 57, rue Cuvier, F-75231 Paris, Cedex 05.

${ }^{\mathrm{B}}$ Wiesenweg 1, A-6063 Rum, Austria.

${ }^{\mathrm{C}}$ Corresponding author. Email: valentin.demazancourt@laposte.net

Caridina longirostris H. Milne Edwards, 1837 described from specimens supposedly from La Macta River near Oran, Algeria, is an emblematic species of the ' $C$. nilotica complex'. Until now this species was thought to have a wide distribution in the Indo-Pacific region. Recently, numerous specimens identified as C. longirostris were collected from various Indo-West Pacific localities. In the context of integrative taxonomy, both old and newly collected specimens were morphologically and genetically studied. Four species allied to C. longirostris are here identified: C. appendiculata Jalihal \& Shenoy, 1998, C. brevidactyla Roux, 1920, C. gracilipes De Man, 1892 and C. meridionalis Roux, 1926. Detailed re-descriptions of these four species are given as well as their geographical and ecological distributions. Caridina nilotica var. brevidactyla is revalidated as the species $C$. brevidactyla, and C. coulaborensis Richard \& Clark, 2014, C. fritzi Richard \& Clark, 2014 and C. solamulieres Richard \& Clark, 2014 are considered junior synonyms of $C$. meridionalis. The position of these species in the troublesome ' $C$. nilotica complex' is clarified and some species are synonymised. A key is provided to facilitate identification.

Additional keywords: Indo-Pacific region, morphology, 16S rRNA.

TOC abstract: Caridina longirostris is a species of freshwater shrimp formerly thought to be widespread in the Indo-Pacific area, but as new specimens were collected, the validity of this species was questionned for most of the localities. Combined morphological and molecular analyses showed that $C$. longirostris is absent from the Indo-Pacific area and that there are four different species previously confused with it in the region. This study helped resolving part of the taxonomic confusion surrounding the $C$. nilotica complex.

\section{Introduction}

One of the aims of the Muséum national d'Histoire naturelle (MNHN), Paris, is to undertake faunistic inventories of rivers on tropical islands in order to establish better protection of these fragile ecosystems and, in this context, to clarify taxonomy of poorly known species. The freshwater shrimp Caridina H. Milne Edwards, 1837, comprising 302 valid species (World Register of Marine Species 
Publisher: CSIRO; Journal: IS:Invertebrate Systematics

Article Type: Research Paper; Volume: ; Issue: ; Article ID: IS18034

DOI: 10.1071/IS18034; TOC Head:

database as of June 2018) and mainly present in the Indo-Pacific region, is the most diversified genus of the Atyidae (De Grave et al. 2015) and an important ecological component in tropical streams (Pringle et al. 1993; Covich et al. 1999). Their high diversity combined with the lack of informative morphological characters has led to a confused taxonomy (Richard and Clark 2009). Indeed, until recently their taxonomy was mainly based on morphological characters. Some have been proven highly variable within a species (e.g. rostrum shape and indentation or colouration; de Mazancourt et al. 2017) and therefore taxonomically non-informative, making it difficult to establish speciation (von Rintelen and Cai 2009). There is thus a need for an integrative and standardised approach to improve the systematics of the group, focusing on informative morphological features and using molecular characters (Page et al. 2005; Page and Hughes 2011).

To illustrate this problem, we here focus on Caridina longirostris H. Milne Edwards, 1837, a species belonging to the troublesome 'C. nilotica complex', described in 1837 by H. Milne Edwards from specimens from La Macta River, near Oran, Algeria. The taxonomic complexity within Caridina has led previous authors to create groups of species based on shared morphological characters. For example, Bouvier (1925) defined five species-groups: C. nilotica-group, C. laevis-group, C. africanagroup, C. brevirostris-group and C. typus-group. Some of these have been further divided as new species were described, such as the C. serrata-group (Cai and Ng 1999; Karge and Klotz 2007), C. gracilirostris-group (Cai and Ng 2007a) and C. weberi-group (Cai and Anker 2004; Cai et al. 2009), while others still exist, such as the C. nilotica and C. typus groups (Karge and Klotz 2007). According to Bouvier (1925), the C. nilotica-group is characterised by the following: (1) antennular peduncles usually equal or exceed three-quarters of the carapace and the sixth abdominal segment by two-thirds; (2) rostrum usually long, curved upwards; (3) uropodal diaeresis with 8-10 short spiniform setae. Until 1900, C. longirostris was one of eight species belonging to the ' $C$. nilotica complex' that now includes 22 different taxa (Karge and Klotz 2007).

Caridina longirostris has been reported as a widely distributed species ranging from the Indian Ocean including Madagascar (Holthuis 1965) and Reunion Island (Keith et al. 2006) and the West Pacific Ocean including New Caledonia (Holthuis 1969; Choy and Marquet 2002; Marquet et al. 2003), Fiji (Choy 1991), Vanuatu (Keith et al. 2010), Australia (Page et al. 2007), Papua New Guinea (Short 2009), Pohnpei (Maciolek and Ford 1987), Sumba (Holthuis 1978), Philippines (Chace 1997) and Taiwan (Hung et al. 1993). However, this species does not occur in the Central Pacific (Keith and Marquet 2011, 2013).

Numerous Caridina specimens were collected from New Caledonia by the Pedcal Expedition in 1991 and by Chloe Expeditions between 1997 and 2002. Similarly, rivers on the islands of Efate, Santo and Malekula (Vanuatu) were sampled in July 2003 and November 2008 by the Vanuatu Environment Unit and the MNHN. Part of this material was identified as C. longirostris (Marquet et al. 2003; Keith et al. 2010). More recently, additional specimens identified as Caridina longirostris 
Publisher: CSIRO; Journal: IS:Invertebrate Systematics

Article Type: Research Paper; Volume: ; Issue: ; Article ID: IS18034

DOI: 10.1071/IS18034; TOC Head:

were collected during trips to Micronesia including Babeldaob, Palau, (in February and March 2011)

and Pohnpei (in March 2012) and Melanesia including Taveuni, Fiji, in February 2013; Efate and Epi, Vanuatu, in November 2014; Aneityum, Vanuatu, in June 2015; Choiseul in October 2014,

Kolobangara in November 2015 and Vella Lavella in October 2016, all Solomon Islands, and New

Caledonia in September and November 2016 and November 2017.

Therefore, the aim of the present study was to combine morphological data with a $16 \mathrm{~S}$ rRNA analysis, so using integrative taxonomy re-examine all old (1991-2008) and recent (2011-2017) specimens from Micronesia and Melanesia and material deposited in five museums to establish the distribution of $C$. longirostris.

\section{Materials and methods}

\section{Abbreviations for museums}

Muséum national d'Histoire naturelle, Paris (MNHN); Naturhistorisches Museum Basel, Basel, Switzerland (NMB); Museum für Naturkunde, Berlin, Germany (ZMB); Rijksmuseum van Natuurlijke Historie (now in the Naturalis Biodiversity Center, Leiden, Netherlands) (RMNH); Zoölogisch Museum Amsterdam (now in the Naturalis Biodiversity Center, Leiden, Netherlands) (ZMA); Bernice Pauahi Bishop Museum, Honolulu, Hawaii (BPBM); Werner Klotz's collection, Rum, Austria (WK).

\section{Morphological comparison}

The rostrum, the general cephalon, pereiopods $1,2,3$ and 5, and the abdomen were observed using a stereoscopic microscope. The proportions of the various joints of the appendages were measured using microphotographs and the AnalySIS Works software (Olympus). Drawings were made using the 'Digital Inking' method (Coleman 2003, 2006) by tracing vectorial paths on high-resolution photographs using Adobe Illustrator (CS6) and a WACOM MPTZ-1230 graphic tablet.

\section{Abbreviations for morphological analyses}

The following abbreviations are used in the present text: cl, carapace length (mm) measured from the post-orbital margin to the posterior margin of the carapace; P1, first pereiopod; P2, second pereiopod; P3, third pereiopod; P5, fifth pereiopod; P11, first male pleopod; Pl2, second male pleopod.

\section{DNA extraction, amplification and sequencing}

For recent specimens, DNA was extracted from abdominal tissues using the semi-automatic Eppendorf ep-Motion 5075 robot. Fragments of the mitochondrial 16S rRNA ( 520 bp) were amplified using newly designed primers, adapted from Palumbi (1996) to our taxa: 16Sar-Lmod (TACTTCTGCCTGTTTATCAAAAA) and 16Sbmod (GGTCTGAACTCAAATCATGTAAA). DNA amplification was performed in $20-\mu \mathrm{L}$ PCR reactions containing $~ 3 \mathrm{ng}$ of template DNA, 2.5 $\mathrm{mM}$ of $\mathrm{MgCl}_{2}, 0.26 \mathrm{mM}$ of each nucleotide, $0.3 \mu \mathrm{M}$ of each primer, $5 \%$ DMSO, $1 \mathrm{ng}$ of BSA and 1.5 
Publisher: CSIRO; Journal: IS:Invertebrate Systematics

Article Type: Research Paper; Volume: ; Issue: ; Article ID: IS18034

DOI: 10.1071/IS18034; TOC Head:

units of QBIOTAQ polymerase (MP Biomedicals, Santa Ana, CA, USA). Amplification products were generated by an initial denaturation step of 4 min at $94^{\circ} \mathrm{C}$ followed by 35 cycles of denaturation at $94^{\circ} \mathrm{C}$ for $30 \mathrm{~s}$, annealing at $52^{\circ} \mathrm{C}$ for $40 \mathrm{~s}$, extension at $72^{\circ} \mathrm{C}$ for $60 \mathrm{~s}$ and a final extension step at $72^{\circ} \mathrm{C}$ for $7 \mathrm{~min}$.

For old collection specimens (types and non-types of C. appendiculata Jalihal \& Shenoy, 1998, C. brachydactyla De Man, 1908, C. brevidactyla Roux, 1920, C. coulaborensis Richard \& Clark, 2014, C. gracilipes De Man, 1892, C. fritzi Richard \& Clark, 2014, C. longirostris, C. meridionalis Roux, 1926, C. peninsularis Kemp, 1918 and C. solamulieres Richard \& Clark, 2014) a CTAB protocol was used to extract DNA from pleopods. A shorter fragment of the 16S rRNA (332 bp) was amplified using the primers 16S-Car-81F (AGGTAGCATAATAAATAGTC) and 16S-Car-413R (CTGTTATCCCTAAAGTAAC) (de Mazancourt et al. 2018). If these primers could not amplify successfully, another reverse primer was used to try to amplify a shorter fragment (141 bp): 16S-Car222R (CTTTATAGGGTCTTATCGT). DNA amplification was performed in 20- $\mu \mathrm{L}$ PCR reactions containing 2.5 of $\mathrm{mM} \mathrm{MgCl}_{2}, 0.26 \mathrm{mM}$ of each nucleotide, $0.3 \mu \mathrm{M}$ of each primer, $1 \mathrm{ng}$ of BSA and 1.5 units of QBIOTAQ polymerase (MP Biomedicals). Amplification products were generated by an initial denaturation step of $4 \mathrm{~min}$ at $94^{\circ} \mathrm{C}$ followed by 45 cycles of denaturation at $94^{\circ} \mathrm{C}$ for $30 \mathrm{~s}$, annealing at $55^{\circ} \mathrm{C}$ for $30 \mathrm{~s}$, extension at $72^{\circ} \mathrm{C}$ for $40 \mathrm{~s}$ and a final extension step at $72^{\circ} \mathrm{C}$ for $7 \mathrm{~min}$.

PCR products were sequenced using the same primers and in both directions to ensure the accuracy of base calls. Chromatograms were edited using Geneious v. 8 software (http://www.geneious.com/ Kearse et al. 2012). All sequences were deposited in GenBank (numbers MH497484 to MH497558).

\section{Molecular analyses}

DNA sequences were aligned using MEGA7 software (Kumar et al. 2016) with the Muscle algorithm (Edgar 2004). Using the Bayesian information criterion in jModelTest (Guindon and Gascuel 2003; Darriba et al. 2012) we retained the GTR + G model. Best-scoring maximum likelihood (ML) trees were estimated using RAxML HPC2 v. 8.2.10 (Stamatakis 2014) and best-scoring Bayesian inference trees were estimated using MrBayes v. 3.2.6 (Ronquist and Huelsenbeck 2003). Both methods were implemented in the Cyber Infrastructure for Phylogenetic Research (CIPRES) portal with the previously determined model, running for 10000000 generations with a sampling frequency of 2000 and a burn-in of $25 \%$. Support for nodes was determined using posterior probabilities calculated by MrBayes implemented in the CIPRES portal v. 3.1. (Miller et al. 2010; https://www.phylo.org/). One hundred independent searches were conducted, each starting from distinct random trees. Robustness of the nodes was assessed using non-parametric bootstrapping (Felsenstein 1985) with 1000 bootstrap replicates. We considered a group to be 'moderately supported' if it had a bootstrap support value (B) between $75 \%$ and $89 \%$ and 'highly supported' if $\mathrm{B} \geq 90 \%$. For the analysis, 11 recent specimens of $C$. brevidactyla from different localities were selected and two sequences retrieved from GenBank, four 
Publisher: CSIRO; Journal: IS:Invertebrate Systematics

Article Type: Research Paper; Volume: ; Issue: ; Article ID: IS18034

DOI: 10.1071/IS18034; TOC Head:

recent specimens of $C$. leucosticta from Okinawa and mainland Japan, four specimens of $C$.

grandirostris from Taiwan and Okinawa, three recent specimens from Sulawesi, one old collection specimen from Bali and one sequence retrieved from GenBank for C. brachydactyla, 11 recent specimens from different localities, four type specimens from Sulawesi, one old collection specimen from Flores and two sequences retrieved from GenBank for $C$. gracilipes, five type specimens for $C$. coulaborensis, two type specimens for $C$. fritzi, six recent specimens and one sequence retrieved from GenBank for C. meridionalis, 22 specimens from different localities for C. appendiculata, two sequences of $C$. sp. indistincta $E$ retrieved from GenBank and, finally, one old collection specimen of C. longirostris from Fiji (see details in Table 1).

\section{Results}

\section{Molecular results}

Due to their old age, DNA could not be extracted with sufficient quantity and quality using our method for the type specimens of $C$. appendiculata, C. brachydactyla, C. brevidactyla, $C$. longirostris, C. meridionalis, C. peninsularis and C. solamulieres; thus, no $16 \mathrm{~S}$ sequence was amplified for these specimens. However, the approach was successful for type specimens of $C$. coulaborensis, C. fritzi, C. gracilipes and non-type specimens of $C$. brachydactyla from Indonesia and C. 'longirostris' from Fiji. Furthermore, we tried to obtain recent specimens from as close as possible to the type locality for C. brachydactyla (Palopo, Sulawesi, Indonesia) and C. meridionalis (New Caledonia). The genetic analysis shows seven well-defined clades (Fig. 1). The first clade (Clade A in Fig. 1) is well supported in the Bayesian analysis $(\mathrm{PP}=1)$ and comprises all the specimens identified as $C$. brevidactyla and a specimen referred to as $C$. longirostris from Fiji. All the others are grouped in a clade sister-group to $C$. brevidactyla (Clade A). This clade is partially unresolved with a polytomy comprising a clade with the specimens of $C$. leucosticta (Clade B, $\mathrm{PP}=1 ; \mathrm{B}=100$ ), another with the specimens of $C$. grandirostris and a GenBank sequence of a specimen referred to as $C$. brachydactyla (Clade $\mathrm{C}, \mathrm{PP}=0.98 ; \mathrm{B}=94$ ) and a third with all the remaining specimens. This third clade, well supported in the Bayesian analysis ( $\mathrm{PP}=0.99)$, is composed of two clades, each divided into two. On one side, a clade composed of recent and old specimens of $C$. brachydactyla (Clade D, $\mathrm{PP}=1 ; \mathrm{B}=100$ ) is sister-group to another with recent, old and type specimens of $C$. gracilipes (Clade $\mathrm{E}, \mathrm{PP}=1 ; \mathrm{B}=100$ ). On the other side, a clade composed of recent specimens of $C$. meridionalis, type specimens of $C$. coulaborensis and type specimens of $C$. fritzi (Clade F, PP $=0.77 ; \mathrm{B}=76$ ) is sistergroup to the specimens of $C$. appendiculata and two specimens referred to as $C$. indistincta $E$ altogether (Clade G, $\mathrm{PP}=1 ; \mathrm{B}=90$ ).

\section{Morphological study}

The morphological examination of many specimens previously identified as $C$. longirostris from different localities allowed five species to be distinguished with support from the molecular data (Fig. 
Publisher: CSIRO; Journal: IS:Invertebrate Systematics

Article Type: Research Paper; Volume: ; Issue: ; Article ID: IS18034

DOI: 10.1071/IS18034; TOC Head:

1): C. longirostris, C. appendiculata (Clade G), C. brevidactyla (Clade A), C. gracilipes (Clade E) and C. meridionalis (Clade F). An identification key and the diagnoses of these five species are given below.

\section{Discussion}

This study provided molecular data from old type specimens of $C$. gracilipes, $C$. coulaborensis and $C$. fritzi, which will help to stabilise the taxonomy of this group. Indeed, the position of the type specimens of $C$. gracilipes in this phylogenetic analysis (Fig. 1) allowed the assignment of other specimens to this species.

Jean Roux (1926a) described C. nilotica meridionalis from seven localities in New Caledonia. These type specimens have been separated by Richard and Clark (2014) into five species: $C$. meridionalis, C. peninsularis and three new species: C. coulaborensis, C. fritzi and C. solamulieres. Numerous specimens were collected in New Caledonia by the Pedcal Expedition in 1991, by Chloe Expeditions between 1997 and 2002, by two authors (VM and GM) in September 2016 and by one author (VM) in November 2016 and November 2017. By examining them and considering the molecular results (Clade F, Fig. 1), C. coulaborensis, $C$. fritzi and $C$. solamulieres are considered junior synonyms of $C$. meridionalis. Indeed, specimens captured near the estuary show a long rostrum with a distal unarmed end characteristic of $C$. coulaborensis, whereas specimens captured in middle courses of rivers possess a shorter rostrum with teeth present on the dorsal margin to the tip characteristic of $C$. meridionalis or $C$. fritzi. The single specimen of $C$. solamulieres would be an aberrant specimen of $C$. meridionalis, with an unusually short rostrum. Indeed, when visiting the type locality, no specimen with this morphology was found.

Some specimens that were incorrectly identified before their sequence was submitted to GenBank can now be attributed to the correct species. RMNH.CRUS.D.54674 from Fiji, identified as ' $C$. longirostris', was nested within our $C$. brevidactyla specimens. Furthermore, the GenBank sequence DQ478528, attributed to ' $C$. brachydactyla' and collected in Bali, is $C$. grandirostris, together with sequences of ' $C$. indistincta $E$ ' from Australia that are assigned to $C$. appendiculata. Some sequences, however, provided valuable information about the geographical range of species, such as the two sequences of $C$. brevidactyla from specimens collected in Papua New Guinea, a locality not sampled in the present study.

The shorter DNA fragments obtained for old collection specimens introduced a significant amount of missing data to the matrix, which explains the lower support values in the tree for some of the clades that contained such sequences. However, the analyses made without the short sequences yielded the same topology.

The analysis was made from a single marker, 16S rRNA. In these conditions, the phylogenetic relationships shown in the tree are to be considered with caution. Using more markers and combining 
Publisher: CSIRO; Journal: IS:Invertebrate Systematics

Article Type: Research Paper; Volume: ; Issue: ; Article ID: IS18034

DOI: 10.1071/IS18034; TOC Head:

mitochondrial and nuclear data would generate more resolved and supported trees. However, this analysis showed that the species are distinct, each clearly separated from the others, a result unlikely to be disproved by further analyses.

The C. nilotica complex

Taxa assigned to the ' $C$. nilotica complex' display incredible morphological variation between populations of the same species, so the characters given here take into account this intra-specific variability. Some characters frequently used to separate Caridina species are (1) the rostrum, (2) the proportions between the joints of pereiopods, (3) the presence or absence of an appendix interna on the endopod of the first male pleopod, (4) the presence of a postero-median projection at the distal margin of the telson, (5) a pre-anal carina with or without a spine, and (6) the size of eggs. Generally, species should be discriminated based on a combination of characters instead of only one. All the species treated in the present study are part of this complex that we consider to be biologically valid and not only an artificial group, as Bouvier (1925) meant it to be. Shared morphological characters are indeed present, such as the slender morphology, with a mostly long rostrum (longer than the antennular peduncle), the antennal spine ventral to the inferior orbital angle, a long antennular peduncle (subequal to carapace length), long leg segments, a typical dorsal hump over the third abdominal somite, a long sixth abdominal somite (always more than half of carapace length), a small pre-anal carina bearing sometimes an acute spine, a moderate number of spinules on the uropodal diaeresis $(<15)$, few medium to short-terminal simple setae on the telson and a rounded endopod of the first male pleopod with or without an appendix on the subdistal outer margin or even placed at the distal end.

\section{The rostrum}

The rostrum length plasticity in atyid shrimps (Jugovic et al. 2010) is, according to de Mazancourt et al. (2017), linked to the environment. In the present study, specimens of $C$. meridionalis captured near the estuary showed a long rostrum with a remarkable proportion of the rostrum unarmed between proximal and apical teeth, while specimens caught in the middle course of rivers showed a shorter rostrum with teeth present on the dorsal margin to the tip. But, the number of teeth and their placement on the rostrum (Richard and Clark 2014) remain important identification characters. For example, C. appendiculata was moved by Cai and $\mathrm{Ng}$ (2007a) from the C. gracilirostris speciesgroup to the $C$. nilotica species-group due to the presence of post-orbital teeth on the rostrum, a diagnostic character of this group. Indeed, C. appendiculata (1-3), C. longirostris (1-2), C. brevidactyla (1-3), C. gracilipes (1-2) and C. meridionalis (1-3) have post-orbital teeth like all $C$. nilotica-group species. Caridina neglecta, however, is maintained in its original species-group because it does not possess post-orbital teeth, a diagnostic character of species in the $C$. gracilirostrisgroup. The rostrum always has some subapical teeth: one for $C$. longirostris, 1-2 for C. gracilipes, 
Publisher: CSIRO; Journal: IS:Invertebrate Systematics

\section{Article Type: Research Paper; Volume: ; Issue: ; Article ID: IS18034}

DOI: 10.1071/IS18034; TOC Head:

and 1-3 for C. appendiculata, C. brevidactyla and C. meridionalis. The number of dorsal teeth on the rostrum is greater for $C$. brevidactyla (16-30), lower for C. appendiculata (12-18) and C. longirostris (14-17), and intermediate for C. gracilipes (12-23) and C. meridionalis (16-26). The number of dorsal teeth on the rostrum before the first ventral tooth is greater for $C$. brevidactyla (11-15), $C$. gracilipes (9-15) and C. meridionalis (10-15), and lower for C. appendiculata (8-12) and C. longirostris (9-12).

\section{The proportions between pereiopod joints}

In our study, P1 and P2 carpus length (respectively 1.4-1.8 and 4.0-4.2) was used to distinguish $C$. longirostris from all the other studied species. It is greater for $C$. brevidactyla (2.5-3.6 and 5.6-7.5), C. appendiculata (1.9-2.8 and 4.4-6.3), C. gracilipes (1.7-2.6 and 4.4-6.3) and C. meridionalis (2.33.5 and 4.1-6.2).

The presence or the absence of an appendix interna on the endopod of the male first pleopod We agree with Richard and Clark (2005) that identifying species based on the presence or absence of appendix interna seems unwarranted. For example, in $C$. gracilipes the appendix interna on the endopod of the male first pleopod can be present or absent (pers. obs.). However, C. appendiculata, C. brevidactyla and C. meridionalis always show an appendix interna, unlike $C$. longirostris in which it is always absent. The presence or absence of the appendix interna in adult specimens could be linked to seasonal variation, depending on the breeding period. During winter, when conditions are less favourable, the appendix interna may disappears and then grows again when the temperatures rise in summer. This could explain the absence of this organ in C. longirostris, as the species is known from a single collecting event supposedly during winter (see below) in an area where seasonality is more marked than the rest of the geographical range of Caridina (Egypt). However, ovigerous females are common among the type material of $C$. longirostris, raising doubts about the breeding condition of this population, or even this species during winter. Similarly, in C. gracilipes, in our material, males without appendix interna were found along with ovigerous females. Furthermore, what would be the evolutionary advantage of reducing and growing the appendix interna several times during the life of the animal? Would some species be able to breed without it? Further investigation should be made to understand the mechanisms of gain and loss of this feature in species where its presence is variable such as $C$. gracilipes.

\section{The telson}

The telsons of C. appendiculata, C. brevidactyla, C. longirostris and C. gracilipes have a posterior margin ending in a median point. Caridina meridionalis, however, is variable in that the posterior margin of the telson does not always end in a medial point. Although the median point is absent in $C$. longirostris, the posterior margin of the telson is sharply triangular compared with relatively triangular in the other species. 
Publisher: CSIRO; Journal: IS:Invertebrate Systematics

Article Type: Research Paper; Volume: ; Issue: ; Article ID: IS18034

DOI: 10.1071/IS18034; TOC Head:

The pre-anal carina spine

Caridina appendiculata, C. gracilipes, C. meridionalis and C. longirostris all possess a spine on the pre-anal carina, which is absent in $C$. brevidactyla. This character is regarded as a significant character.

Egg size

Although all studied species were considered to have small eggs, their size is regarded as a significant character. Caridina meridionalis had the largest eggs at $0.34-0.75 \times 0.24-0.48 \mathrm{~mm}$, then intermediate for C. brevidactyla $(0.37-0.47 \times 0.22-0.30 \mathrm{~mm})$, C. appendiculata $(0.38-0.46 \times 0.23-0.28 \mathrm{~mm})$ and C. gracilipes $(0.32-0.46 \times 0.18-0.27 \mathrm{~mm})$, and smallest for C. longirostris $(0.33-0.39 \times 0.21-0.26$ $\mathrm{mm})$. However, C. meridionalis eggs were smaller near the estuary and larger in the middle course of rivers. Also, differences in egg size between riverine and lacustrine specimens were reported for $C$. gracilipes (Han et al. 2011).

\section{Distribution (Fig. 2)}

The present study considers that $C$. longirostris is not present in the following localities.

\section{Micronesia}

This species was reported by Leberer and Nelson (2001) from Guam and Pohnpei by Maciolek and Ford (1987). Recently, a new species, C. variabilis de Mazancourt, Rogers \& Keith, 2018, was described from Palau and Guam and another from Pohnpei currently under consideration (de Mazancourt et al. in press).

\section{Melanesia}

Short (2009) described $C$. longirostris with a rostral formula (5-30/2-22 vs $14-17 / 10-15)$ and P1 carpus (2-3 times longer than broad vs 1.4-1.8), which suggests that this species does not occur in the Mimika Region, New Guinea. Three allied species occur in the Solomon Islands including $C$. appendiculata (Kolobangara), C. brevidactyla (Choiseul, Kolobangara, Vella Lavella) and a new species. Caridina longirostris has been confused in Vanuatu (Keith et al. 2010) until now with $C$. appendiculata or C. brevidactyla, in New Caledonia (Holthuis 1969; Choy and Marquet 2002;

Marquet et al. 2003) with C. brevidactyla and C. meridionalis J. Roux, 1926, and in Fiji (Choy 1991) with C. brevidactyla.

\section{Australia}

According to Page et al. (2007), C. longirostris does not occur in Australia. Specimen DQ478497 identified as $C$. gracilirostris from north Johnstone River is in fact $C$. gracilipes. 
Publisher: CSIRO; Journal: IS:Invertebrate Systematics

Article Type: Research Paper; Volume: ; Issue: ; Article ID: IS18034

DOI: 10.1071/IS18034; TOC Head:

\section{West Pacific}

The report of Chace (1997) from the Philippines is either C. elongapoda Liang \& Yan, 1977 or $C$. gracilipes (see Cai and Shokita 2006). The specimens reported by Holthuis (1978) from Sumba and by Schenkel (1902) from Sulawesi (Indonesia) and Taiwan by Hung et al. (1993) are C. gracilipes. The latter species is a common atyid shrimp in fresh and brackish waters of Taiwan (Ueno 1935; Yu 1974; Shy and Yu 1998; Cai and Shokita 2006). Characters described by Hung et al. (1993) are 14-24 dorsal teeth on rostrum (13-20 in C. gracilipes vs 14-17 in C. longirostris), P1 carpus more than two times as long as wide (1.7-3.4 in C. gracilipes vs 1.4-1.8 in C. longirostris), $\mathrm{P} 2$ carpus more than five times as long as wide (4.4-6.4 in C. gracilipes vs 3.9-4.7 in C. longirostris).

In summary, C. longirostris is not present in Indo-West Pacific islands but some morphologically close species were identified: C. appendiculata, C. brevidactyla, C. gracilipes and C. meridionalis (see Fig. 2 for the distribution range of these species).

\section{Key for the studied species}

1.1 Pre-anal carina without spine. C. brevidactyla

1.2 Pre-anal carina with spine. .2

2.1 P1 carpus mostly 1.7-1.8 times as long as wide and P2 carpus mostly 3.9-4.2 as long as wide $C$. longirostris

2.2 P1 carpus mostly 1.9-3.6 times as long as wide and P2 carpus mostly 4.3-6.5 as long as wide. 3

3.1 Relatively large eggs $0.34-0.75 \times 0.24-0.48 \mathrm{~mm}$; telson mostly rounded without a median process................. meridionalis

3.2 Small eggs $0.32-0.47 \times 0.18-0.30 \mathrm{~mm}$; telson always with posterior margin triangular, ending in a posteromedian projection. . .4

4.1 P3 propodus mostly 4.6-7.1 times as long as dactylus, P5 propodus mostly 4.5-6.2 times as long as dactylus C. appendiculata

4.2 P3 propodus mostly 3.5-4.5 times as long as dactylus, P5 propodus mostly 3.3-4.2 times as long as dactylus. C. gracilipes 


\section{Taxonomy}

Family ATYIDAE De Haan, 1849

Genus Caridina H. Milne Edwards, 1837

Caridina longirostris H. Milne Edwards, 1837

Caridina longirostris H. Milne Edwards, 1837: 363; De Man, 1892: 395-397, fig. 291, m; 1908: 264-265, plate XX, fig. 5, 5a, 5b mm; Bouvier, 1905: 78; 1925: 149-151, figs 313-314 (partim) 1925: 150, fig. 314; Richard \& Clark, 2009: fig. 4d, e, f.

Not Caridina longirostris Bouvier, 1925: 151.

Not Caridina longirostris. Bouvier, 1925: 151 (partim); Holthuis, 1969: 94-97; 1978: 36; Maciolek \& Ford, 1987: 628; Choy, 1991: 354; Hung et al., 1993: 493-494, fig. 8; Chace, 1997: 14, figs 6, 7; Leberer \& Nelson, 2001: 389; Liang, 2004: 195, fig. 94; Choy \& Marquet, 2002: 217; Marquet et al., 2003: 60-61; Page et al., 2007: 647; Short, 2009: 42, fig. 31; Keith et al., 2010: 42-43.

\section{Material examined}

Paralectotypes. $\quad$ MNHN Na 746, 3ð $\mathrm{cl} 2.9-3.1 \mathrm{~mm}$; MNHN-IU-2013-19418, 2ð 3.2-3.6 mm; MNHN IU-2013-19417, 2 ovig. cl 3.1-3.3 mm; from the River Macta, near Oran, Algeria.

Other material examined. Not C. nilotica longirostris. Indonesia: MNHN-IU-2015-1741, 10 $\mathrm{cl} 2.2$ mm; MNHN-IU-2015-1891, 1ð̂ cl 2.3 mm, Makassar, Sulawesi.

\section{Diagnosis}

Carapace (Fig. 3G): smooth, glabrous, with sharp antennal spine placed at lower orbital angle. Pterygostomian margin blunt. Rostrum long, 1.0-1.2 of cl, curved up distally, reaching well beyond scaphocerite; $14-17$ dorsal teeth, leaving distally unarmed part of rostrum $0.7-1.1$ times that of armed part, except for one or two subapical teeth, 1-2 post-orbital teeth present. 10-15 teeth present on the ventral margin extending from highest part of the rostrum either to tip or with short distal part unarmed. Number of dorsal teeth on the rostrum before the most proximal ventral tooth 9-12. Rostral formula: (1-2) 14-17+ 1-2/ 10-15.

First pereiopod (Fig. 3A): stouter than second pereiopod; chela 1.6-2.1 times as long as wide, dactylus 2.2-3.3 times as long as wide, 1.0-1.5 length of palm; carpus 1.4-1.8 times as long as wide with shallow excavation on anterior margin.

Second pereiopod (Fig. 3B): more slender and longer than first pereiopod; chela 1.9-2.4 times as long as wide, dactylus 3.0-3.6 times as long as wide, 1.3-1.6 times length of palm; carpus 3.9-4.7 times as long as wide. 
Publisher: CSIRO; Journal: IS:Invertebrate Systematics

Article Type: Research Paper; Volume: ; Issue: ; Article ID: IS18034

DOI: 10.1071/IS18034; TOC Head:

Third pereiopod (Fig. 3C, D): dactylus 4.0-4.8 times as long as wide (terminal spine included) with 7-9 spiniform setae on flexor margin in addition to the terminal one; propodus 11.3-14.3 times as long as wide, 3.4-4.0 times as long as dactylus.

Fifth pereiopod (Fig. 3E, F): dactylus 4.5-5.1 times as long as wide with 32-38 spiniform setae on flexor margin; propodus 13.4-16.1 times as long as wide, 3.2-3.7 as long as dactylus.

Telson (Fig. 3M): ending sharply triangular with a posteromedian projection; one pair of longer lateral simple setae and two pairs of clearly shorter intermediate simple setae.

First male pleopod (Fig. $3 K$ ): endopod leaf-like without a developed appendix interna.

Second male pleopod (Fig. $3 L$ ): appendix masculina on second pleopod reaching 0.62 times length of endopod; appendix interna reaching $\sim 0.58$ times length of appendix masculina.

Pre-anal carina (Fig. 3I): with a spine.

Uropodal diaeresis (Fig. 3H): with 9-12 short spinules.

Eggs (Fig. 3J): size $0.36-0.40 \times 0.22-0.30 \mathrm{~mm}$.

\section{Colour pattern}

Unknown.

\section{Distribution}

According to Bouvier (1925), 'Jusqu'ici les seuls représentants connus de cette variété sont les nombreux exemplaires types du Caridina longirostris qui, d'après H. Milne-Edwards, furent capturés dans la rivière de la Macta, près d'Oran, par M. Roux. Or, on ne connaît en Algérie qu'un Atyidé, l'Atyaëphyra Desmaresti, si bien qu'on peut dire, presque sans aucun doute que les types de MilneEdwards proviennent d'une région tout autre que l'Algérie' ('Until now, the only representatives known for this variety are the numerous type specimens of Caridina longirostris which, according to H. Milne Edwards, were captured in La Macta River, near Oran, by M. Roux. However, we only know one Atyidae from Algeria, Atyaëphyra Desmaresti, so we can say almost without a doubt that Milne Edwards' type specimens come from a region other than Algeria'). He believed that they would have come from the Celebes area, as he found specimens identified as C. nilotica gracilipes by Schenkel (1902) from Makassar (Celebes Island) to be morphologically close to the type specimens (Bouvier 1925). After having examined these specimens, we concluded that they were young individuals of $C$. gracilipes. Thus, the exact type locality remained unknown. We hypothesised that if the locality was erroneous on the specimen label, maybe the collector was not. The 'M. Roux' indicated by H. Milne Edwards was his contemporary Jean Louis Florent Polydore Roux (17921833), more commonly referred to as Polydore Roux. The life and times of Polydore Roux are well documented including two published letters (J. L. F. P. Roux 1833, 1834) addressed to a M. le baron 
Publisher: CSIRO; Journal: IS:Invertebrate Systematics

Article Type: Research Paper; Volume: ; Issue: ; Article ID: IS18034

DOI: 10.1071/IS18034; TOC Head:

de Férussac, an obituary (Barthélemy 1834) and a biographical account by P.-M. Roux (son of Polydore) (P.-M. Roux 1834). Accordingly, Polydore Roux was appointed the conservateur du Cabinet d'histoire naturelle de Marseille on 1 June 1819. Consequently, it would have been relatively easy for him to travel to Algeria and collect at 'Rivière de la Macta, près d'Oran', but there is no mention of J. L. F. P. Roux visiting Algeria, although there are several references that confirm he left France on 6 September 1831 with Baron Karl von Hugel and the pair arrived in Egypt towards the end of that month. They both travelled widely in the region including up the Nile to Nubia (now in Sudan), along the coast of the Red Sea and part of Arabia, collecting specimens along the way. While in Egypt, J. L. F. P. Roux (1833) addressed a letter to M. le Baron de Férussac, which was published by the Annales des Sciences Naturelles and figured Pelias (now Caridina) niloticus and Palaemon niloticus (now Macrobrachium niloticum). According to Richard and Clark (2005), the figured type specimen is no longer extant as P.-M. Roux later sold his father's collections to dealers such as Dupont in Paris. Furthermore, Baron Karl von Hugel and Polydore parted company in Egypt with J. L. F. P. Roux travelling up the Nile to Kené (now Qena or Qiná) and catching a caravan to Cosseyyre (Al Qusayr or Quseir) on the Red Sea. Here he caught a steamship to Bombay (now Mumbai). On 8 March 1832 he sailed through the Strait of Bab el Mandael on the coast of Abyssinia and a few days later arrived in Bombay. According to P.-M. Roux (1834), Polydore explored the chain of Ghats and collected freshwater Crustacea before he died of the plague in Bombay on 12 April 1833. We think that he may have collected other species of shrimps in Egypt that somehow ended up in the collections of the MNHN in Paris. There was at this time a locality named Arawat el Macta (Linant de Bellefonds 1843), now called Hawwarat Al Maqta $\left(29^{\circ} 15.471^{\prime} \mathrm{N} 30^{\circ} 53.785^{\prime} \mathrm{E}\right)$, in the Faiyum Governorate crossed by a channel linking the Lake Qarun to the Nile river. We know that Roux visited the Faiyum Oasis in winter 1831 (P.-M. Roux 1834), so it is not unlikely that he collected shrimps from this locality that he preserved with the indication 'El Macta'. Henri Milne Edwards, examining specimens from this collect in 1837 would have assumed that the specimens came from the well-known Macta River in Algeria (where a military battle took place between French troops and the Algerian resistance just two years before), unaware of the existence of such a name in Egypt and was not able to get the locality corrected by P. Roux who died in 1833 in India. The probability is indeed much higher that $C$. longirostris is present in Egypt than in Algeria since Caridina exists in the Nile watershed, about a thousand kilometres of desert away from Oran. A new field trip to Hawwarat Al Maqta may allow confirmation or not of the presence of $C$. longirostris in this locality and validate it as the type locality. Considering the locality, the only congeneric species present would be $C$. nilotica, a species that can morphologically be separated from $C$. longirostris. Furthermore, new samples of this species may allow verification of the morphological data provided here and obtain molecular data to place this species in the phylogeny and ascertain its validity. 
Publisher: CSIRO; Journal: IS:Invertebrate Systematics

Article Type: Research Paper; Volume: ; Issue: ; Article ID: IS18034

DOI: 10.1071/IS18034; TOC Head:

\section{Habitat}

Unknown.

\section{Remarks}

The paralectotypes re-examined for this study fit well with the description given by De Man (1908): rostrum long, reaching well beyond scaphocerite, curved up distally with presence of 0-2 post-orbital teeth (vs 1-2 in the present study), 14-21 dorsal teeth (vs 14-17 in the present study) and 11-17 ventral teeth (vs 10-15 in the present study); P1 carpus 1.5-1.9 times as long as wide (vs 1.4-1.8 in the present study); P2 carpus 3.4-4.7 times as long as wide (vs 3.9-4.7 in the present study). P3 dactylus with 7-10 spiniform setae (vs 7-9 in the present study) propodus 3.4-3.7 as long as dactylus (vs 3.4-4.0 in the present study); P5 dactylus with 30-39 spiniform setae (vs 32-38 in the present study), propodus 14.7-18.0 times as long as wide (vs 13.4-16.1 in the present study) and propodus 3.2-3.5 times as long as dactylus (vs 3.2-3.7 in the present study); uropodal diaresis 11-13 spinules (vs $9-12$ in the present study); small eggs $0.33-0.39 \times 0.21-0.26 \mathrm{~mm}$ (vs $0.36-0.40 \times 0.22-0.30 \mathrm{~mm}$ in the present study). Some values given by Bouvier (1925) are also similar to the $C$. longirostris material examined for the present study: P3 dactylus with 7-10 spines (vs 7-9 in the present study), P5 dactylus with 29-38 spiniform setae (vs 32-38 in the present study), uropodal diaeresis with 1113 spinules (vs $9-12$ in the present study), small eggs $0.33-0.39 \times 0.20-0.22 \mathrm{~mm}$ (vs $0.36-0.40 \times$ $0.22-0.30 \mathrm{~mm}$ in the present study). Also, our specimens fit well with the brief description given by Richard and Clark (2009: 13) with a rostral formula (1-2) 14-20/13-16 (vs (1-2) 14-17/10-15 in the present study), a telson that terminates in a sharply triangular posterior margin with a posteromedian projection and three pairs of distal spiniform setae, the lateral pair of which is distinctly longer than intermediates (see also Bouvier 1925: 150, fig. 315), and a pre-anal carina having a distinct spine.

Thus, the morphology of $C$. longirostris is defined by its short P1 and P2 carpus respectively 1.41.8 and 3.9-4.7 times as long as wide. Consequently, $C$. longirostris could be separated from all the members of the $C$. nilotica-group studied here: C. appendiculata, C. brevidactyla, C. gracilipes and C. meridionalis (see below).

According to Schenkel (1902: fig. 5a, pl. 8), who examined specimens collected in Makassar, Sulawesi, the P1 of C. gracilipes appears similar to that of C. longirostris (De Man 1892: fig. 201, tab. XXIV). In addition, Schenkel (1902) indicates further similarities between these two species including P1 carpus 1.5 times as long as wide (vs 1.4-1.8 for C. longirostris, present study) and P5 dactylus with 27 spiniform setae (vs 32-38 for C. longirostris, present study). According to Bouvier (1925), specimens of C. gracilipes reported by Schenkel (1902) from Makassar include two young specimens of $C$. longirostris (MNHN-IU-2015-1741 and MNHN-IU-2015-1891), the P5 propodus being 3.5 times as long as dactylus as in C. longirostris (vs 3.2-3.7 for C. longirostris, present study). These two specimens of Bouvier were re-examined and were found not to be $C$. longirostris 
Publisher: CSIRO; Journal: IS:Invertebrate Systematics

Article Type: Research Paper; Volume: ; Issue: ; Article ID: IS18034

DOI: 10.1071/IS18034; TOC Head:

according to their longer $\mathrm{P} 1$ and $\mathrm{P} 2$ carpus 2.1-2.2 times as long as wide (vs 1.4-1.8 for $C$.

longirostris, present study) and 5.0-5.1 (vs 3.9-4.7 for C. longirostris, present study). The P3

propodus dimension of the Makassar specimens are 10.1-12.2 and are within the range variation of $C$. gracilipes (vs 10.2-16.0) but not for C. appendiculata (vs 13.8-22.7) or C. brevidactyla (vs 13.224.9). These two specimens from Makassar are considered juveniles of $C$. gracilipes.

Caridina appendiculata Jalihal \& Shenoy, 1998 (Fig. 4)

Caridina appendiculata Jalihal \& Shenoy, 1998: 128; Klotz et al., 2007: 7-9, figs 3 (part), 4.

Caridina sp. E Page et al., 2007: 648, table 1; Cook et al., 2011: 278, fig 3.

\section{Material examined}

Lectotype. ZMA.CRUS.D.102646, 10 cl 3.1 mm; Caridina gracilirostris De Man, 1892, Indonesia: Flores: river near Bari, coll. M. Weber, 1888.

Paralectotypes. $\quad 1 \delta^{\lambda} \mathrm{cl} 2.9 \mathrm{~mm}, 3$ ㅇ $\mathrm{cl} 2.2-4.3 \mathrm{~mm}$; same data as lectotype.

Other material examined. Australia: MNHN-IU-2018-117, 10 $\mathrm{cl} 2.8 \mathrm{~mm}$ (DNA: CA1668) and MNHN-IU-2018-118, 10 cl 4.0 mm (DNA: CA1667); River Hastings: Bain Bridge crossing near Crossroads, $31^{\circ} 26.150^{\prime} \mathrm{S} 152^{\circ} 42.283^{\prime} \mathrm{E}$, coll. B. Mos, 9.vii.2016; MNHN-IU-2018-119, 1 q cl 3.1 mm, MNHN-IU-2018120, 1 cl 3.5 mm, MNHN-IU-2018-121, 1 c cl 4.8 mm (DNA: CA1665), MNHN-IU-2018-122, 1 ㅇ cl 5.4 $\mathrm{mm}$ and MNHN-IU-2018-123, $10^{\Uparrow} \mathrm{cl} 3.1 \mathrm{~mm}$; River Clarence: near Cowper/Brushgrove, 29³4.067'S 15304.633'E, coll. B. Mos, 2.vii.2016; MNHN-IU-2018-124, 10ิ $\mathrm{cl} 2.8$ mm (DNA: CA1670) and MNHNIU-2018-125, $10^{\top} \mathrm{cl} 3.5 \mathrm{~mm}$ (DNA: CA1669); Warrell Creek, 3045.583'S 152 53.217'E, coll. B. Mos, 9.vii.2016. Indonesia: Sulawesi: ZMB 29000, 4^ cl 3.4-3.7 mm, 2 q ovig. cl 4.3-5.1 mm; Luwuk Peninsula: freshwater spring in Malontong, west of Ampana, brackish water pool, $0^{\circ} 53.125^{\prime} \mathrm{S} 121^{\circ} 31.371^{\prime} \mathrm{E}$, coll. $\mathrm{M}$.

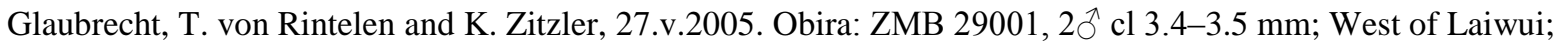
$1^{\circ} 21.613^{\prime}$ S 127³6'421. 9.ix.2005. Palau: MNHN-IU-2018-127, 1 ㅇ ovig. cl 3.9 mm (DNA: CA1021); Babeldaob, small stream East Coast, near the estuary, altitude 0 m, $07^{\circ} 29.909^{\prime} \mathrm{N}, 134^{\circ} 38.099^{\prime} \mathrm{E}$, coll. P. Keith, P. Gerbeaux, G. Marquet, L. Taillebois and M. Castelin, 2.iii.2011. Micronesia: MNHN-IU-2018-128, 1 ㅇ ovig. cl 3.2 mm and MNHN-IU-2018-129, 1 ㅇ ovig. cl 3.6 mm (DNA: CA1333); River Nanpil: estuary, Pohnpei Island, altitude $5 \mathrm{~m}, 06^{\circ} 56.609^{\prime} \mathrm{N}, 158^{\circ} 13.550^{\prime} \mathrm{E}$, coll. P. Keith, P. Gerbeaux, G. Marquet, L. Taillebois and M. Castelin, 13.iii.2012; MNHN-IU-2018-130, 1 q ovig. cl 3.0 mm (DNA: CA1330), MNHN-IU-2018131, 1 ㅇ ovig. cl $3.4 \mathrm{~mm}$ and MNHN-IU-2018-132, 1 q $\mathrm{cl} 3.1 \mathrm{~mm}$; unnamed river, estuary, Pohnpei Island, altitude $5 \mathrm{~m}, 06^{\circ} 48.579^{\prime} \mathrm{N}, 158^{\circ} 12.639^{\prime} \mathrm{E}$, coll. P. Keith, P. Gerbeaux, G. Marquet, L. Taillebois and M. Castelin, 15.iii.2012. Solomon Islands: Kolobangara: MNHN-IU-2018-133, $1 \hat{\jmath}$ cl 3.5 mm (DNA: CA1493) and MNHN-IU-2018-134, $1 \widehat{o}^{\uparrow} \mathrm{cl} 3.6 \mathrm{~mm}$; River Zamba, altitude $0 \mathrm{~m}, 08^{\circ} 05.934^{\prime} \mathrm{S} 157^{\circ} 00.830^{\prime} \mathrm{E}$, coll. P. Keith, G. Marquet and C. Lord, 9.xi.2015; MNHN-IU-2018-135, 1 \% ovig. cl 4.0 mm (DNA: CA1494), MNHN-IU2018-136, 1 ㅇ ovig. cl $4.1 \mathrm{~mm}$ and MNHN-IU-2018-137, 1 त $\mathrm{cl} 3.3 \mathrm{~mm}$; River Vanga, altitude $5 \mathrm{~m}$, 
Publisher: CSIRO; Journal: IS:Invertebrate Systematics

Article Type: Research Paper; Volume: ; Issue: ; Article ID: IS18034

DOI: 10.1071/IS18034; TOC Head:

07'54.825'S $156^{\circ} 57.762^{\prime}$ E, coll. P. Keith, G. Marquet and C. Lord, 18.xi.2015. Vanuatu: Aneityum: MNHN-

IU-2018-138, 1 cl 3.7 mm; River Inuje, altitude 0 m, 20¹3.321'S 16945.899'E, coll. C. Lord and G. Segura, 25.vi.2015; MNHN-IU-2018-139, 1 q 3.8 mm and MNHN-IU-2018-140, $1 ð 2.5$ mm (DNA: CA1489) River Inwe Lengei, altitude 9 m, 20¹3.915'S 16947.385'E, coll. C. Lord and G. Segura, 24.vi.2015; EPI: MNHNIU-2018-141, 1 q ovig. cl 4.5 mm; River Buavinai, 16²48.189'S 168¹1.079'E, coll. P. Keith, G. Marquet and M. Mennesson, 27.x.2014; EFATE: MNHN-IU-2018-146, 1 q ovig. cl 4.6 mm, MNHN-IU-2018-143, 1 ㅇ ovig. cl 4.7 mm (DNA: CA1264), MNHN-IU-2018-144, 1 q ovig. cl 4.7 mm (DNA: CA1268), MNHN-IU2018-145, 1 q ovig. cl $4.8 \mathrm{~mm}$, MNHN-IU-2018-147, 1 + cl 4.7 mm, MNHN-IU-2018-148, 1 cl $4.9 \mathrm{~mm}$, MNHN-IU-2018-149, $1 \widehat{\jmath} \mathrm{cl} 3.4 \mathrm{~mm}$ and MNHN-IU-2018-150, $1 \widehat{\jmath} \mathrm{cl} 3.8 \mathrm{~mm}$; Creek Ai, altitude: $2 \mathrm{~m}$, $17^{\circ} 36.627^{\prime} \mathrm{S} 168^{\circ} 14.525^{\prime} \mathrm{E}$, coll. P. Keith, G. Marquet and M. Mennesson, 9.xi.2014. MNHN-IU-2018-156, 1 ㅇ ovig. cl 4.2 mm (DNA: CA1259) and MNHN-IU-2018-157, 1 ovig. cl 4.6 mm (DNA: CA1261); Creek Marona, altitude $5 \mathrm{~m}, 17^{\circ} 33.860^{\prime} \mathrm{S} 168^{\circ} 17.140^{\prime} \mathrm{E}$, coll. P. Keith, G. Marquet and M. Mennesson, 9.xi.2014; SANTO: MNHN-IU-2018-158, 1 ㅇ cl 4.2 mm; Jackie’s Blue Hole, 15²18.788'S $167^{\circ} 10.208^{\prime}$ E, coll. P. Keith and G. Marquet, 22.vii.2003.

\section{Diagnosis}

Carapace (Fig. 4G, $N, O$ ): smooth, glabrous, with sharp antennal spine placed at lower orbital angle. Pterygostomian margin blunt. Rostrum long, 1.3-2.1 of cl, curved up distally, reaching well beyond scaphocerite. 12-18 dorsal teeth somewhat irregular spaces, leaving distally unarmed part of rostrum 0.5-1.2 times that of armed part, except for 1-3 subapical teeth, 1-3 post-orbital teeth present; 8-25 teeth present of the ventral margin extending from proximal end either to tip or with short distal part unarmed. Number of dorsal teeth on the rostrum before the first ventral tooth 8-12. Rostral formula: (1-3) $12-18+1-3 / 8-25$.

First pereiopod (Fig. 4A): slender, chela 1.7-2.4 times as long as wide, dactylus 3.1-4.3 times as long as wide, 1.1-1.7 length of palm; carpus 1.9-2.8 times as long as wide with shallow excavation on anterior margin.

Second pereiopod (Fig. 4B): more slender and longer than first pereiopod: chela 2.0-2.7 times as long as wide, dactylus 3.3-5.5 times as long as wide, 1.1-1.6 times length of palm; carpus 4.8-7.1 times as long as wide.

Third pereiopod (Fig. 4C, D): dactylus 2.9-4.1 times as long as wide, terminal spine included, with 6-8 spines on flexor margin in addition to the terminal one; propodus 13.8-22.7 times as long as wide, 4.4-7.1 times as long as dactylus.

Fifth pereiopod (Fig. 4E, F): dactylus 3.8-5.2 times as long as wide with 33-44 spiniform setae on flexor margin; propodus 13.7-26.2 times as long as wide, 4.3-6.2 times as long as dactylus.

Telson (Fig. 4M): ending in a posteromedian projection; three pairs of distal simple setae, lateral pair slightly longer than intermediate. 
Publisher: CSIRO; Journal: IS:Invertebrate Systematics

Article Type: Research Paper; Volume: ; Issue: ; Article ID: IS18034

DOI: 10.1071/IS18034; TOC Head:

Pre-anal carina (Fig. 4I): with a prominent finger-like backward striking tooth.

First male pleopod (Fig. 4K): endopod leaf-like with well-developed appendix interna.

Second male pleopod (Fig. 4L): appendix masculina on second pleopod reaching 0.61-0.66 times length of endopod; appendix interna reaching $0.70-0.71$ times length of appendix masculina.

Uropodal diaeresis (Fig. 4H): with 8-12 short spinules.

Eggs (Fig. 4J): size $0.38-0.46 \times 0.23-0.28 \mathrm{~mm}$.

\section{Colour pattern}

Colour varies in live specimens and tends to match their background. The colour of the body is hyaline with many red dots (Fig. $8 A, B)$.

\section{Distribution}

Caridina appendiculata is now known from Australia (present study), Indonesia (Flores (Cai and Ng 2007a), Obira (present study) and Sulawesi (Klotz et al. 2007)), Solomon Islands (Kolobangara, present study), Micronesia (Pohnpei, present study), Palau (present study) and Vanuatu (Aneityum, Efate, Epi and Santo, present study) (Fig. 2).

\section{Habitat}

All specimens were collected in a typical brackish water environment (brackish water pool or the lower part of rivers, near the estuary).

\section{Remarks}

Our specimens of $C$. appendiculata agree well with the descriptions by Klotz et al. (2007) of this species from Sulawesi (Indonesia): long rostrum reaching well beyond scaphocerite 1.3-2.2 (vs 1.32.1 in the present study), curved up distally with presence of $2-3$ post-orbital teeth (vs 1-3 in the present study), 9-20 dorsal teeth (vs 12-18 in the present study) and 13-29 ventral teeth (vs 8-25 in the present study); P1 carpus 1.8-3.2 (vs 1.9-2.8 in the present study); P2 carpus 5.0-7.7 (vs 4.8-7.1 in the present study). P3 dactylus with 6-8 spines (vs 6-8 in the present study) propodus $4.5-7.1$ as long as dactylus (vs 4.4-7.1 in the present study); P5 dactylus with 37 spiniform setae (vs 33-44 in the present study), propodus 16.0-26.7 times long as width (vs 13.7-26.2 in the present study) and propodus 4.5-6.0 times as long as dactylus (vs 4.3-6.2 in the present study); P11 endopod with a long appendix interna; pre-anal carina with a prominent finger-like backward striking tooth; telson ending in a median point, three pairs of distal spiniform setae, lateral pair slightly longer than intermediate; uropodal diaeresis $9-13$ spinules (vs 8-12 in the present study) and egg size $0.41-0.46 \times 0.16-0.26$ $\mathrm{mm}$ (vs $0.38-0.46 \times 0.23-0.28 \mathrm{~mm}$ in the present study).

Our specimens with a long and upcurved rostrum and apical teeth were for a long time associated with the C. gracilirostris species-group. According to Cai and $\mathrm{Ng}$ (2007a), C. appendiculata was 
Publisher: CSIRO; Journal: IS:Invertebrate Systematics

\section{Article Type: Research Paper; Volume: ; Issue: ; Article ID: IS18034}

DOI: 10.1071/IS18034; TOC Head:

moved from the $C$. gracilirostris species-group to the $C$. nilotica species-group due to the presence of post-orbital teeth (1-3) on the rostrum, a diagnostic character of the latter. Moreover, our specimens differed from this group by the larger number of teeth on the dorsal margin of the rostrum, 12-18 (vs 3-11 in the $C$. gracilirostris-group), a smaller number of ventral teeth, 8-25 (vs 19-36 in the $C$. gracilirostris-group).

\section{Comparison}

In the $C$. nilotica species-group, $C$. appendiculata resembles $C$. longirostris, $C$. brevidactyla, $C$. gracilipes and $C$. meridionalis, particularly by the long rostrum with subapical teeth.

Caridina appendiculata can be distinguished from $C$. longirostris by the carpus length in P1, 1.92.8 (vs 1.4-1.8 in C. longirostris); the carpus length in $\mathrm{P} 2,4.8-7.1$ (vs 3.9-4.7 in C. longirostris), $\mathrm{P} 3$ with stouter dactylus 2.9-4.1 times as long as wide (vs 4.0-4.8 in C. longirostris); P3 propodus 4.47.1 times as long as dactylus (vs 3.4-4.0 in C. longirostris); P5 stouter with propodus 4.3-6.2 times as long as dactylus (vs 3.2-3.7 in C. longirostris).

Although difficult, $C$. appendiculata can be differentiated from $C$. brevidactyla by the prominent spine on the pre-anal carina (vs absent in C. brevidactyla); the smaller number of teeth on the proximal part of the dorsal margin of the rostrum being 12-18 somewhat irregular spaced (vs 16-30 more closely set in $C$. brevidactyla); a smaller number of dorsal teeth behind the first ventral teeth 812 (vs 11-15 in C. brevidactyla); a shorter P1 carpus, 1.9-2.8 (vs 2.5-3.6 in C. brevidactyla); a slightly smaller number of spiniform setae on the dactylus of P5, 33-44 (vs 35-53 in C. brevidactyla); a more slender appendix masculina on second pleopod reaching $0.61-0.66$ times length of endopod (vs 0.54-0.55 in C. brevidactyla); and a shorter appendix interna reaching 0.70-0.71 times length of appendix masculina (vs $0.77-0.81$ in C. brevidactyla).

Caridina appendiculata differs from C. gracilipes in a higher number of ventral teeth on rostrum, 8-25 (vs 7-17 in C. gracilipes); a smaller number of dorsal teeth behind the first ventral teeth, 8-12 (vs 9-15 in C. gracilipes); a more slender P3 propodus, 13.8-22.7 times as long as wide (vs 10.2-16.0 in C. gracilipes); a slightly smaller number of spiniform setae on the P5 dactylus, 33-44 (vs 34-58 in C. gracilipes) and a more slender P5 propodus, 4.3-6.2 times as long as dactylus (vs 3.3-4.5 in $C$. gracilipes).

Specimens of $C$. appendiculata examined for the present study only differ from C. meridionalis in a smaller number of dorsal teeth on the rostrum, 12-18 (vs 16-26 in C. meridionalis); a smaller number of dorsal teeth behind the first ventral teeth, 8-12 (vs 10-15 in C. meridionalis); a slightly smaller number of spiniform setae on the P5 dactylus, 33-44 (vs 42-62 in C. meridionalis) and smaller eggs $0.38-0.46 \times 0.23-0.28 \mathrm{~mm}$ (vs $0.34-0.75 \times 0.24-0.48 \mathrm{~mm}$ in C. meridionalis). 
Publisher: CSIRO; Journal: IS:Invertebrate Systematics

Article Type: Research Paper; Volume: ; Issue: ; Article ID: IS18034

DOI: 10.1071/IS18034; TOC Head:

Caridina brevidactyla Roux, 1920

(Fig. 5)

Caridina nilotica var. brevidactyla J. Roux, 1920: 320-321; 1926a: 204-206.

Caridina brevidactyla Cai \& Ng, 2001: 671, fig. 5.

\section{Material examined}

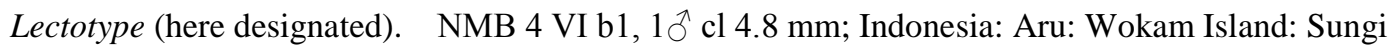
Manumbai 14-15.iv.1908.

Paralectotypes. $\quad$ NMB 4 VI a, $1 \partial^{\wedge} \mathrm{cl} 3.3$ mm; Indonesia: Udjir Island, 15.iv.1908. NMB 4 VI b, 2 c cl 5.8-6.4 mm; Sungi Manumbai: Wokam Island: Aru, 14-15.iv.1908. NMB 4 VI c, 1 ㅇ cl 5.7 mm; Wokamar: Wokam Island: Aru; 17.iv.1908. NMB 4 VI d, 2 q ovig. cl 5.7 mm; Kobroor Island: Seltutti: Aru; 2.v.1908.

Other material examined. Fiji: Ovalau: RMNH.CRUS.D.54674, 1 cl 4.6 mm; River Lovoni, $17^{\circ} 41^{\prime} 20^{\prime \prime} \mathrm{S} 178^{\circ} 47^{\prime} 45^{\prime \prime} \mathrm{W}$, coll. S. C. Choy, 26.vii.1980; Taveuni: MNHN-IU-2018-159, $1 \widehat{\partial}^{\Uparrow} \mathrm{cl} 3.1 \mathrm{~mm}$ (DNA: CA1426); Bouma National Heritage Park, altitude $13 \mathrm{~m}, 16^{\circ} 49.599^{\prime} \mathrm{S} 179^{\circ} 52.557^{\prime} \mathrm{W}$, coll. P. Keith and G. Marquet, 26.ii.2013; unknown island: BPBM 3947, 1 q cl 4.3 mm; unknown locality, coll. C. H. Edmonson, 1933. New Caledonia: MNHN-IU-2018-160, 1 ㅇ ovig. cl $4.3 \mathrm{~mm}$, MNHN-IU-2018-161, 1 ㅇ cl $4.5 \mathrm{~mm}$ (DNA: CA1007), MNHN-IU-2018-162, 1 cl $4.6 \mathrm{~mm}$ and MNHN-IU-2018-163, 1 cl $5.0 \mathrm{~mm}$; River Tibarama, altitude $5 \mathrm{~m}, 20^{\circ} 56.300^{\prime} \mathrm{S} 165^{\circ} 22.700^{\prime} \mathrm{E}$, coll. G. Marquet and L. Taillebois, 23.x.2010; MNHN-IU-

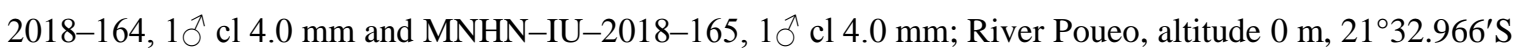
$165^{\circ} 30.062^{\prime} \mathrm{E}$, coll. G. Marquet and V. de Mazancourt, 28.ix.2016. Solomon Islands: Choiseul: MNHN-IU2018-168, 1 우 ovig. cl 5.3 mm (DNA: CA1305); River Gu'ma, altitude 50 m, 0701.764'S 156²49.899'E, coll. P. Keith, G. Marquet and M. Mennesson, 17.x.2014; MNHN-IU-2018-169, 1 ㅇ ovig cl 5.0 mm, MNHN-IU2018-170, 1 ㅇ ovig cl $5.1 \mathrm{~mm}$, MNHN-IU-2018-171, 19 ovig cl 5.7 mm (DNA: CA1346) and MNHN-IU2018-172, 1 ㅇ ovig cl 5.8 mm (DNA: CA1345); River Lokasereke, altitude 45 m, 06 $58.024^{\prime} \mathrm{S} 156^{\circ} 47.861^{\prime} \mathrm{E}$, coll. P. Keith, G. Marquet and M. Mennesson, 13.x.2014. MNHN-IU-2018-XXX, 1 ㅇ cl $4.4 \mathrm{~mm}$ and MNHNIU-2018-XXX, $1 \delta^{\Uparrow} \mathrm{cl} 3.3 \mathrm{~mm}$; River Lopakare, upstream, altitude $50 \mathrm{~m}, 07^{\circ} 01.613^{\prime} \mathrm{S} 156^{\circ} 45.567^{\prime} \mathrm{E}$, coll. P. Keith, G. Marquet and M. Mennesson, 20.x.2014; MNHN-IU-2018-XXX, 1 q ovig. cl 5.0 mm (DNA: CA1302), MNHN-IU-2018-173, 1 ㅇ ovig. cl 5.3 mm and MNHN-IU-2018-174, 1 ڤิ cl 3.1 mm; River Vorama, altitude 15 m, 06 $58.687^{\prime} \mathrm{S} 156^{\circ} 46.746^{\prime} \mathrm{E}$, coll. P. Keith, G. Marquet and M. Mennesson, 11.x.2014. KOLOBANGARA: MNHN-IU-2018-178, 1ㅇ ovig. cl 4.2 mm and MNHN-IU-2018-179, 1 ㅇ ovig. cl 4.9 mm; River Lodumoe, altitude 0 m, $07^{\circ} 50.961^{\prime} \mathrm{S} 157^{\circ} 04.320^{\prime} \mathrm{E}$, coll. P. Keith, G. Marquet and C. Lord, 16.xi.2015; MNHN-IU-2018-180, 1 \% ovig. cl 3.7 mm, MNHN-IU-2018-181, 19 ovig. cl 3.9 mm and

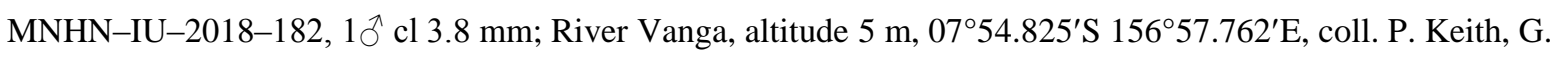
Marquet and C. Lord, 18.xi.2015; Vella Lavella: MNHN-IU-2018-183, 1 + ovig cl 4.6 mm and MNHN-IU2018-184, 10`; River Maravari, $07^{\circ} 51.703^{\prime}$ S $156^{\circ} 41.748^{\prime} \mathrm{E}$, coll. P. Keith and C. Lord, 31.x.2016; MNHN-IU2018-186, 1 ㅇ ovig. cl $4.0 \mathrm{~mm}$ and MNHN-IU-2018-187, 1 ð $\mathrm{cl} 4.2 \mathrm{~mm}$; River Wariassi, coll. P. Keith and C. Lord, 29.x.2016. Vanuatu: EPI: MNHN-IU-2018-188, 1 q cl 5.1 mm (DNA: CA1307); River Buavinai, $16^{\circ} 48.189^{\prime}$ S $168^{\circ} 11.079^{\prime}$ E, coll. P. Keith, G. Marquet and M. Mennesson, 27.x.2014. EFATE: MNHN-IU- 
Publisher: CSIRO; Journal: IS:Invertebrate Systematics

Article Type: Research Paper; Volume: ; Issue: ; Article ID: IS18034

DOI: 10.1071/IS18034; TOC Head:

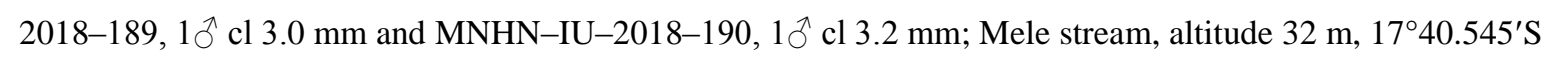

$168^{\circ} 15.558^{\prime}$ E, coll. P. Keith, G. Marquet and M. Mennesson, 9.xi.2014; Malekula: MNHN-IU-2018-191, 1 ㅇ ovig. cl. $4.3 \mathrm{~mm}$ and MNHN-IU-2018-192, 1 q cl $4.0 \mathrm{~mm}$; River Brenwe, 1607.986'S 167 17.148' E, coll. P. Keith, L. Taillebois and C. Lord, 20.xi.2008; Santo: MNHN-IU-2018-193, 1 ovig. cl 5.0 mm and MNHNIU-2018-194, 1 웅 ovig. cl 5.1 mm; Jackie’s Blue Hole, altitude 0 m, 15²18.788'S $167^{\circ} 10.208^{\prime} \mathrm{E}$, coll. P. Keith and G. Marquet, 22.vii.2003.

\section{Comparative material}

Caridina grandirostris Stimpson, 1860

Japan: ZRC 2004-0519, $1 \hat{\jmath} \mathrm{cl} 3.4 \mathrm{~mm}, 1 \hat{\mathrm{cl}} 3.8 \mathrm{~mm}$ (DNA: CA1892), $1 q$ ovig. $\mathrm{cl} 6.1 \mathrm{~mm}$ and $1 q \mathrm{cl}$ 4.7 mm (DNA: CA1891); upstream of Tima River, $\sim 1-2 \mathrm{~km}$ from river mouth, Okinawa Island, Ryukyu Islands, $26^{\circ} 33.42^{\prime} \mathrm{N} 128^{\circ} 04.60^{\prime} \mathrm{E}$, coll. Cai, Ng, Taruse and Islam, 11.vi.2000. ZRC 2004-0530, 19 ovig. cl. 5.0 mm (DNA: CA1893); freshwater stream draining to a small patch of mangrove, Oura River, Okinawa Island,

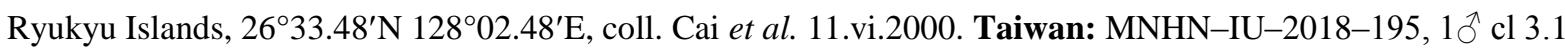
mm (DNA: CA1676); Pingtung, river near Jialeshui Coastal rock formations, altitude $2 \mathrm{~m}, 21^{\circ} 59.305^{\prime} \mathrm{N}$ $120^{\circ} 49.956^{\prime}$ E, coll. W. and M. Klotz and M.-C. Liu, 25.vii.2013.

Caridina leucosticta Stimpson, 1860

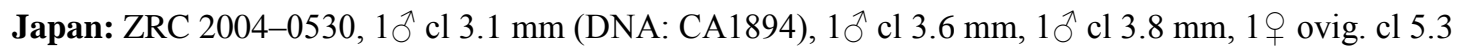
mm and 19 ovig. cl $6.1 \mathrm{~mm}$ (DNA: CA1896); freshwater stream draining to a small patch of mangrove, Oura River, Okinawa Island, Ryukyu Islands, $26^{\circ} 33.48^{\prime} \mathrm{N} 128^{\circ} 02.48^{\prime} \mathrm{E}$, coll. Y. Cai, N. K. Ng, T. Naruse and S. Islam. 11.vi.2000.

\section{Diagnosis}

Carapace (Fig. 5G, $N, O$ ): smooth, glabrous, with sharp antennal spine placed at lower orbital angle. Pterygostomian margin rounded. Rostrum long, 1.1-2.1 of cl, curved up distally, reaching well beyond scaphocerite; 16-30 dorsal teeth regular spaces, leaving distally unarmed part of rostrum 0.61.3 times that of armed part, except for 1-3 subapical teeth, 1-3 post-orbital teeth present; 12-24 teeth present of the ventral margin extending from proximal end either to tip or with short distal part unarmed. Number of dorsal teeth on the rostrum before the first ventral tooth 11-15. Rostral formula: (1-3) $16-30+1-3 / 12-24$.

First pereiopod (Fig. 5A): slender, chela $~ 2.1-2.5$ times as long as wide, dactylus 3.4-4.8 times as long as wide, 1.1-1.9 length of palm; carpus 2.5-3.6 times as long as wide with shallow excavation on anterior margin.

Second pereiopod (Fig. 5B): more slender and longer than first pereiopod, chela 2.6-3.5 times as long as wide, dactylus 4.6-6.8 times as long as wide, 1.3-2.1 times length of palm; carpus 5.6-7.5 times as long as wide. 
Publisher: CSIRO; Journal: IS:Invertebrate Systematics

Article Type: Research Paper; Volume: ; Issue: ; Article ID: IS18034

DOI: 10.1071/IS18034; TOC Head:

Third pereiopod (Fig. 5C, D): dactylus 2.8-4.6 times as long as wide, terminal spine included, with 4-8 spines on flexor margin in addition to the terminal one; propodus 13.2-24.9 times as long as wide, 4.7-8.4 times as long as dactylus.

Fifth pereiopod (Fig. 5E, F): dactylus 3.6-7.4 long as wide with 35-53 spiniform setae on flexor margin; propodus 19.1-29.1 times as long as wide, 4.7-6.2 as long as dactylus.

Telson (Fig. 5M): ending in a posteromedian projection; 3-4 pairs of distal simple setae, lateral pair longer than intermediate.

First male pleopod (Fig. 5K): endopod leaf-like with well-developed appendix interna.

Second male pleopod (Fig. 5L): appendix masculina on second pleopod reaching 0.54-0.55 times length of endopod; appendix interna reaching $0.77-0.81$ times length of appendix masculina.

Pre-anal carina (Fig. 5I): without a spine.

Uropodal diaeresis (Fig. 5H): with 9-13 spinules.

Eggs (Fig. 5J): size 0.37-0.47 ×0.22-0.30 mm.

\section{Colour pattern}

The colour of the body is hyaline with many red dots. An oblique carmine red band on the cephalothorax is characteristic (Fig. $8 C, D$ ).

\section{Distribution}

Caridina brevidactyla is now known from Indonesia (Aru Island (Roux 1920), Halmahera (Cai and Ng 2001)), Solomon Islands (Kolobangara, Vella Lavella, present study), Vanuatu (Efate, Epi, Malekula and Santo, present study), New Caledonia and Fiji (present study) (Fig. 2).

\section{Habitat}

The specimens were collected in the lower reach of the rivers, rarely found in brackish conditions.

\section{Remarks}

The specimens examined for the present study fit well with the descriptions by Cai and $\mathrm{Ng}$ (2001) of this species from Halmahera (Indonesia): the long rostrum reaching well beyond scaphocerite curved up distally with the presence of 2-3 post-orbital teeth (vs 1-3 for the present study); 19-25 dorsal teeth (vs 16-30 for the present study) and 18-23 ventral teeth (vs 12-24 for the present study); P1 carpus 2.2 (vs 2.5-3.6 for the present study); P2 carpus 5.8 (vs 5.6-7.5 for the present study); P3 dactylus with 5-6 spines (vs 4-8 for the present study); propodus 6.2 times as long as dactylus (vs 4.7-8.4 for the present study); P5 dactylus with 57 spiniform setae (vs 38-53 for the present study); propodus 6.0 times as long as dactylus (vs 4.7-6.2 for the present study); Pl1 endopod with a long appendix interna (vs Pl1 endopod with a long appendix interna for the present study); pre-anal carina 
Publisher: CSIRO; Journal: IS:Invertebrate Systematics

\section{Article Type: Research Paper; Volume: ; Issue: ; Article ID: IS18034}

DOI: 10.1071/IS18034; TOC Head:

without spine (vs without for the present study); telson ending in a median point, seven distal simple setae, lateral pair longer than intermediate (vs telson ending in a median point, 3-4 pairs of distal simple setae, lateral pair longer than intermediate for the present study); uropodal diaeresis with 12 spinules (vs 9-13 for the present study); eggs size $0.41 \times 0.25 \mathrm{~mm}$ (vs $0.37-0.46 \times 0.22-0.30 \mathrm{~mm}$ for the present study).

The co-types have an equal number of specimens showing a pre-anal carina with a spine and without a spine and are likely a mix of species. For example, the specimen NMB 4 VI c with 17 dorsal teeth on the rostrum somewhat irregularly spaced, 17 ventral teeth and nine dorsal teeth on the rostrum behind the first ventral one is probably C. appendiculata.

\section{Comparison}

In the $C$. nilotica species-group, $C$. brevidactyla resembles $C$. longirostris, $C$. appendiculata (see above), C. grandirostris, C. gracilipes and C. meridionalis particularly by the long rostrum with subapical teeth.

Caridina brevidactyla is distinct from $C$. longirostris: the spine on the pre-anal carina present in $C$. longirostris is absent in C. brevidactyla, P1 carpus is longer, 2.5-3.6 (vs 1.4-1.8 in C. longirostris); P2 carpus longer 5.6-7.5 (vs 3.9-4.7 in C. longirostris); P3 dactylus stouter, 2.8-4.6 times as long as wide (vs 4.0-4.8 in C. longirostris); a longer propodus, 4.7-8.4 times as long as wide (vs 3.4-4.0 in C. longirostris); P5 stouter with propodus 4.7-6.2 times as long as dactylus (vs 3.2-3.7 in $C$. longirostris).

Choy (1991) described C. longirostris from Fiji (specimens RMNH 54674, 54691, 54733) and considered the specimens identified as C. nilotica brachydactyla (specimens BPBM S3941, S3947) collected by Edmondson (1935) as belonging to this species. Re-examination of all these specimens show that they belong to $C$. brevidactyla with the spine absent from the pre-anal carina (vs spine present on the pre-anal carina in C. longirostris and C. brachydactyla) and numerous dorsal teeth on the rostrum, 20-24 (vs 14-17 in C. longirostris and 16-22 in C. brachydactyla). Also, some specimens from Vanuatu (Keith et al. 2010) and New Caledonia (Marquet et al. 2003) were confused with C. longirostris.

Specimens of $C$. grandirostris examined for the present study compare well with the material from Japan re-described by Cai et al. (2006) and this species is here reported from Taiwan (specimen wk04-13 g3) for the first time. Caridina brevidactyla can be distinguished from C. grandirostris by the absence of a spine on the pre-anal carina (vs present in C. grandirostris); P1 carpus being longer, 2.5-3.6 (vs 2.4-2.8 in C. grandirostris).

Specimens of $C$. leucosticta examined for the present study compare well with the material from Ryukyu Islands, Japan, and re-described by Cai et al. (2006) and like $C$. brevidactyla, the spine on the 
Publisher: CSIRO; Journal: IS:Invertebrate Systematics

\section{Article Type: Research Paper; Volume: ; Issue: ; Article ID: IS18034}

DOI: 10.1071/IS18034; TOC Head:

pre-anal carina is absent. However, $C$. brevidatyla, when compared with $C$. leucosticta, have a longer P1 carpus, 2.5-3.6 (vs 2.2-2.4 in C. leucosticta); a slender P3 propodus, 13.2-24.9 times as long as wide (vs 12.4-15.7 in C. leucosticta) and a slender P5 propodus 19.1-29.1 times as long as wide (vs 18.5-19.9 in C. leucosticta).

Specimens of $C$. brevidactyla examined for the present study are similar to $C$. gracilipes but differ in the absence of a tooth on the pre-anal carina (vs present in $C$. gracilipes); by the P3 propodus slender 4.7-8.4 times as long as dactylus (vs 3.5-4.9 in C. gracilipes) and by a P3 propodus slender 13.2-24.9 times as long as wide (vs 10.2-16.0 in C. gracilipes).

Our specimens of $C$. brevidactyla resemble $C$. meridionalis but can be distinguished by the tooth on the pre-anal carina always being absent (vs present in C. meridionalis); by a longer P2 carpus, 5.67.5 (vs 4.1-6.2 in C. meridionalis); by a slender P5 propodus, 4.7-6.2 times as long as dactylus (vs 3.2-5.3 in C. meridionalis), by a slender P5 propodus 19.1-29.1 times as long as wide (vs 15.3-22.7 in C. meridionalis) and by smaller eggs, $0.37-0.47 \times 0.22-0.30 \mathrm{~mm}$ (vs $0.34-0.75 \times 0.24-0.48 \mathrm{~mm}$ in C. meridionalis).

According to Richard and Clark (2010), C. nilotica var. brevidactyla is a junior synonym of $C$. brachydactyla. Nevertheless, agreeing with Cai and $\mathrm{Ng}$ (2001), we consider $C$. brevidactyla as a valid species. Indeed, the spine on the pre-anal carina present in $C$. brachydactyla is absent in $C$.

brevidactyla.

Caridina gracilipes De Man, 1892

(Fig. 6)

Caridina wyckii var. gracilipes De Man, 1892: 387, fig. 29a-e.

Caridina wyckii var. gracilipes Schenkel, 1902: 498.

Caridina nilotica var. gracilipes De Man, 1908: 270, pl. XX, fig. 7a, b; Kemp, 1918: 275.

Caridina gracilipes Cai, 2014: 208-209, figs 1-3; Cai \& Shokita, 2006: 250.

Caridina gracilipes Richard \& Clark, 2014: 310-314, fig. 4-5.

Caridina longirostris Bouvier, 1925: 151.

Caridina longirostris Holthuis, 1978: 36. C. nilotica var. gracilipes, Roux, 1926a: 203-204 (partim).

Caridina brachydactyla Richard \& Clark, 2010: 308-310, fig. 3.

\section{Material examined}

Paralectotypes. Indonesia: Caridina gracilipes De Man, 1892. ZMA.CRUS.D.102635, 1 đิ $\mathrm{cl} 4.1 \mathrm{~mm}$ (DNA: CA025), 1 ovig. cl 5.9 mm (DNA: CA023), $3 q$ cl 5.1 mm (DNA: CA027), 5.2 mm (DNA:CA024) and 
Publisher: CSIRO; Journal: IS:Invertebrate Systematics

Article Type: Research Paper; Volume: ; Issue: ; Article ID: IS18034

DOI: 10.1071/IS18034; TOC Head:

$5.6 \mathrm{~mm}$; in a rice field, Makassar, Sulawesi, coll. M. Weber, 1888; NMB 1061e, 1 ^ $3.8 \mathrm{~mm}$; 2 q cl 5.8-5.9 mm; same data.

Other material examined. Australia: MNHN-IU-2018-196, $19 \mathrm{cl} 6.3 \mathrm{~mm}$ and MNHN-IU-2018197, $1 \delta^{\Uparrow} \mathrm{cl} 3.7 \mathrm{~mm}$; River Mulgrave, near Aloomba, altitude $8 \mathrm{~m}, 1^{\circ} 08.783^{\prime} \mathrm{S} 145^{\circ} 52.783^{\prime} \mathrm{E}$, coll. B. Mos, 7.vi.2016; MNHN-IU-2018-198, 1 q ovig cl 4.6 mm; Captain Cook Highway crossing, altitude 7 m,

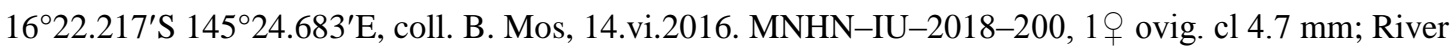
Johnstone, near Innisfail, altitude 7 m; 17³0.317'S 14559.517'E, coll. B. Mos 11.vi.2016; MNHN-IU-2018-

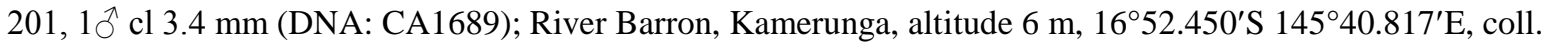
B. Mos 08.vi.2016; MNHN-IU-2018-203, 1ð̋ cl 4.5 mm (DNA: CA1700); Gordon's Creek, Cairns, altitude 15

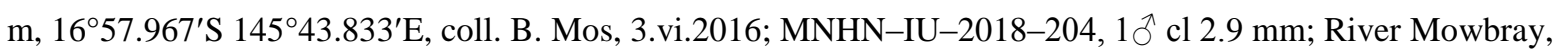
upstream of Diggers Bridge, altitude $18 \mathrm{~m}, 1^{\circ} 33.800^{\prime} \mathrm{S} 145^{\circ} 27.850^{\prime} \mathrm{E}$, coll. B. Mos, 14.vi.2016. MNHN-IU2018-206, 1 q ovig. cl 6.5 mm; Tributary of Moody’s Creek, near Mooroobool, altitude 18 m, 1656.550'S 14543.700’E, coll. B. Mos, 3.vi.2016. Indonesia: Flores Island: Konga: Nusa Tenggara Timu: NMB 1061f, $1 \lesssim$ cl 2.9 mm; 1 q cl 4.5 mm (DNA: CA029) and 1 + cl 4.9 mm; MNHN-IU-2018-207, $10 \hat{~ c l ~} 4.4$ mm (DNA: CA1348); Lombok Island: not C. longirostris NMB 990a, $1 \jmath^{\jmath} \mathrm{cl} 4.1 \mathrm{~mm}$ and $1 q$ ovig. cl $5.9 \mathrm{~mm}$; Sumba Island: East Sumba: Laiwuhi Brook, S. of Melolo, coll. E. Sutter, 31.v.1949. Taiwan: MNHN-IU-2018-208, $1 \jmath^{\Uparrow} \mathrm{cl} 3.6$ mm (DNA: CA1674); Pingtung, river near Jialeshui Coastal rock formations, altitude $2 \mathrm{~m}, 21^{\circ} 59.305^{\prime} \mathrm{N}$ 120 49.956'E, coll. W. and M. Klotz and M.-C. Liu, 25.vii.2013. Borneo: MNHN-IU-2018-209, 1 q cl $4.7 \mathrm{~mm}$ (DNA: CA1673); from ornamental shrimp wholesaler in Singapore. Sri Lanka: MNHN-IU-2018-210, 1 웅 ovig cl 4.8 mm (DNA: CA1825) and MNHN-IU-2018-211, 1ð cl 3.2 mm; Kandalama Reservoir, near to the shore in dead aquatic plants, altitude $184 \mathrm{~m}, 07^{\circ} 52.612^{\prime} \mathrm{N} 80^{\circ} 41.503^{\prime} \mathrm{E}$, coll. W. Klotz, 8.ii.2017. MNHN-IU-

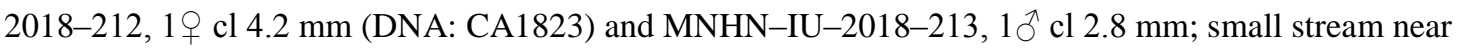
Kekirawa, altitude 130 m, $08^{\circ} 2.050^{\prime} \mathrm{N} 80^{\circ} 35.999^{\prime}$ E, coll. W. Klotz 8.ii.2017; MNHN-IU-2018-214, 1 우 ovig.

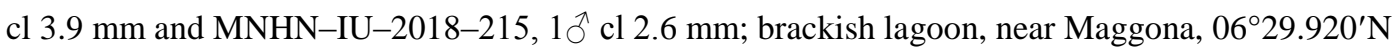
7958.849'E, coll. W. Klotz, 13.ii.2017.

\section{Diagnosis}

Carapace (Fig. 6G, $N, O$ ): smooth, glabrous, with sharp antennal spine placed at lower orbital angle. Pterygostomian margin blunt. Rostrum long, 0.8-1.5 of cl, curved up distally, reaching well beyond scaphocerite; 12-23 dorsal teeth closely set, leaving distally unarmed part of rostrum 0.5-1.2 times that of armed part, except for one or two subapical teeth, 1-2 post-orbital teeth present; $7-17$ teeth present of the ventral margin extending from proximal end either to tip or with short distal part unarmed. Number of dorsal teeth on the rostrum behind the first ventral tooth 9-15. Rostral formula: (1-2) $12-23+1-2 / 7-17$.

First pereiopod (Fig. 6A): chela 1.8-2.5 times as long as wide, dactylus 2.8-4.6 times as long as wide, 0.8-1.4 length of palm; carpus 1.8-2.6 times as long as wide with shallow excavation on anterior margin. 
Publisher: CSIRO; Journal: IS:Invertebrate Systematics

Article Type: Research Paper; Volume: ; Issue: ; Article ID: IS18034

DOI: 10.1071/IS18034; TOC Head:

Second pereiopod (Fig. 6B): more slender and longer than first pereiopod, chela 2.4-2.8 times as

long as wide, dactylus 3.8-5.1 times as long as wide, 1.1-1.7 times length of palm; carpus 4.4-6.3

times as long as wide.

Third pereiopod (Fig. $6 C, D$ ): dactylus 3.2-4.6 times as long as wide, terminal spine included, with 7-9 spines on flexor margin in addition to the terminal one; propodus 10.2.2-16.0 times as long as wide, 3.3-4.5 times as long as dactylus.

Fifth pereiopod (Fig. 6E, F): dactylus 4.4-6.6 as long as wide with 34-58 spiniform setae on flexor margin; propodus 15.1-19.9 times as long as wide, 3.4-5.8 as long as dactylus.

Telson (Fig. 6M): broad, posterior margin triangular, ending in a posteromedian projection; one pair of long lateral spiniform setae and 2-3 pairs of intermediate simple setae clearly shorter than lateral simple setae.

Firs male pleopod (Fig. $6 K)$ : endopod leaf-like with or without appendix interna in males.

Second male pleopod (Fig. $6 L$ ): appendix masculina on second pleopod reaching 0.62 times length of endopod; appendix interna reaching 0.73 times length of appendix masculina.

Pre-anal carina (Fig. 6I): with a spine.

Uropodal diaeresis (Fig. 6H): with 8-13 short spinules.

Eggs (Fig. 6J): size $0.32-0.46 \times 0.18-0.27 \mathrm{~mm}$.

\section{Colour pattern}

The colour of the body is hyaline with many red dots. An oblique punctiform band on the cephalothorax is visible (Fig. $8 E, F)$.

\section{Distribution}

Caridina gracilipes is known from Australia (present study), Borneo (Wowor et al. 2004; present study), Indonesia (Flores, Selayar, Sulawesi (De Man 1892) and Lombok (present study)), India (Kemp 1918), Peninsular Malaysia (Wowor et al. 2004), the Philippines (Cai and Shokita 2006), Singapore (Cai and Ng 2007b), southern China (Kemp 1918; Cai 2014), Sri Lanka (present study), Taiwan (Cai and Shokita 2006; present study) and Vietnam (Li and Liang 2002) (Fig. 2).

\section{Habitat}

Caridina gracilipes can be found in lowlands rivers in freshwater, near estuaries in brackish water or in lakes.

\section{Remarks}

Specimens of $C$. gracilipes examined for the present study fit well with the descriptions by De Man (1908) of this species: the long rostrum reaching well beyond scaphocerite, curved up distally with 
Publisher: CSIRO; Journal: IS:Invertebrate Systematics

Article Type: Research Paper; Volume: ; Issue: ; Article ID: IS18034

DOI: 10.1071/IS18034; TOC Head:

presence of 1-2 post-orbital teeth (vs 2 by De Man 1908); 13-20 dorsal teeth (vs 13-20 by De Man 1908) and 9-17 ventral teeth (vs 11-17 by De Man 1908); P1 carpus 1.7-3.4 (vs 2-2.3 by De Man 1908); P2 carpus 4.4-6.4 (vs 5.4-5.5 by De Man 1908); P3 dactylus with 6-9 spines (vs 9-10 by De Man 1908); propodus 3.5-5.1 as long as dactylus (vs 3.8-4.4 by De Man 1908); P5 dactylus with 28-58 spiniform setae (vs 46-57 by De Man 1908); propodus 14.3-27.4 times long as width (vs 1719 by De Man 1908) and propodus 3.2-5.4 times as long as dactylus (vs 3.7-3.8 by De Man 1908).

Our specimens agree with the description given by Richard and Clark (2014), with a bifid slender rostrum $0.8-1.7$ of cl (vs $1.0-1.1$ by Richard and Clark 2014); 13-20 dorsal teeth (vs 12-24 by Richard and Clark 2014) and 9-17 ventral teeth (vs 12-21 by Richard and Clark 2014); P1 carpus 1.7-3.4 (vs 1.9-2.2 by Richard and Clark 2014); P2 carpus 4.4-6.4 (vs 5.5-6.3 by Richard and Clark 2014); P3 propodus 3.5-5.1 as long as dactylus (vs 3.5-5.3 by Richard and Clark 2014); P5 dactylus 3.2-5.4 times long as wide (vs 3.3-4.3) with 28-58 spiniform setae (vs 55-70 by Richard and Clark 2014); small eggs $0.32-0.42 \times 0.20-0.18 \mathrm{~mm}$ (vs $0.35-0.39 \times 0.19-0.23 \mathrm{~mm}$ by Richard and Clark 2014); pre-anal carina with a spine; diaeresis with 9-13 spinules (vs 9-12 by Richard and Clark 2014). Our material also compare well with the study of Cai and Shokita (2006) with 13-20 dorsal teeth rostrum (vs 11-27 by Cai and Shokita 2006) and 9-17 ventral teeth (vs 8-18 by Cai and Shokita 2006); P1 carpus 1.7-3.4 (vs 2.0-2.5 by Cai and Shokita 2006); P2 carpus 4.4-6.4 (vs 5.4-6.3 by Cai and Shokita 2006); P3 propodus 3.5-5.1 as long as dactylus (vs 3.8-4.4 by Cai and Shokita 2006); P5 dactylus 3.6-5.3 times long as wide (vs 3.1-3.8 by Cai and Shokita 2006) with 28-58 spiniform setae (vs 36-57 by Cai and Shokita 2006); smaller eggs $(0.32-0.43 \times 0.18-0.25 \mathrm{~mm}$ vs $0.42-0.53 \times 0.23-$ $0.33 \mathrm{~mm}$ by Cai and Shokita 2006); pre-anal carina with a spine and diaeresis with 9-13 spinules (vs $8-12$ by Cai and Shokita 2006).

\section{Comparison}

In comparison with $C$. longirostris, $C$. gracilipes has a similar rostral formula, (1-2) 12-23 + 1-2/717 (vs (1-2) 14-17+1/14-17 for C. longirostris) but the number of dorsal teeth on the rostrum behind the first ventral tooth is greater, 9-15 (vs 9-12 for C. longirostris); P1 and P2 carpus are respectively longer, 1.7-2.6 and 4.4-6.3 (vs 1.4-1.8 and 3.9-4.7 for C. longirostris) and P5 propodus 3.3-4.5 times as long as dactylus (vs 3.2-3.7for C. longirostris).

Caridina gracilipes is distinguishable from $C$. meridionalis by the P1 carpus being shorter, 1.7-2.6 (vs 2.3-3.5 in C. meridionalis) and smaller eggs, $0.32-0.46 \times 0.18-0.27 \mathrm{~mm}$ (vs $0.34-0.75 \times 0.24-$ $0.48 \mathrm{~mm}$ in C. meridionalis).

Caridina meridionalis Roux, 1926

(Fig. 7)

Caridina nilotica var. meridionalis J. Roux, 1926a: 207, partim. 
Publisher: CSIRO; Journal: IS:Invertebrate Systematics

Article Type: Research Paper; Volume: ; Issue: ; Article ID: IS18034

DOI: 10.1071/IS18034; TOC Head:

Caridina meridionalis Richard \& Clark, 2014: 321-323, figs 11-12.

Caridina coulaborensis Richard \& Clark, 2014: 324-326, fig. 13.

Caridina fritzi Richard \& Clark, 2014: 326-329, fig. 14.

Caridina solamulieres Richard \& Clark, 2014: 329-331, fig. 15.

Not Caridina nilotica var. meridionalis Roux, 1926b: 246-247.

\section{Material examined}

Holotype. Caridina coulaborenis Richard \& Clark, 2014. New Caledonia: River Coula, near Boréaré, NMB 1057a, $1 \widehat{\jmath} \mathrm{cl} 4.1$ mm (DNA: CA064); coll. F. Sarasin and J. Roux, 6.ii.1912.

Paratype. Caridina coulaborenis Richard \& Clark, 2014, 1 ovig. cl 5.0 mm; NMB 1057b, 1 cl 5.8 mm; same data as holotype.

Paratypes. Caridina coulaborenis Richard \& Clark, 2014. NMB 1057c, $1 \delta^{\lambda} 4.3 \mathrm{~mm}$ and 1 q $\mathrm{cl} 5.0 \mathrm{~mm}$; Koné, coll. F. Sarasin and J. Roux, 9.viii.1911; NMB 1057d, 10 cl 2.6 mm and 1 q cl 4.4 mm (DNA: CA048); La Foa, coll. F. Sarasin and J. Roux, 16.i.1912.

Holotype. Caridina fritzi Richard \& Clark, 2014. New Caledonia: River Coula, near Boréaré, NMB 1058a, $1 \delta^{\mathrm{cl}} 2.8 \mathrm{~mm}$; coll. F. Sarasin and J. Roux, 6.ii.1912.

Paratypes. Caridina fritzi Richard \& Clark, 2014, New Caledonia: Coindé, NMB 1058c, $2 \widehat{\jmath} \mathrm{cl} 2.5 \mathrm{~mm}$ (DNA: CA052) and 2.6 mm (DNA: CA053); coll. F. Sarasin and J. Roux, 12.i.1912.

Holotype. Caridina solamulieres Richard \& Clark, 2014, New Caledonia: Tiouaka, NMB 1059a, $1 q \mathrm{cl}$ 4.5 mm; coll. F. Sarasin and J. Roux, 20.viii.1911.

Lectotype. Caridina meridionalis Roux, 1926. New Caledonia: near Pemboa, NMB 1056a, $1 \widehat{\jmath} \mathrm{cl} 2.7$ mm; coll. F. Sarasin and J. Roux, 1.v.1911;

Paralectotype. Caridina meridionalis Roux, 1926. NMB 1056b, 19 ovig cl $4.2 \mathrm{~mm}$ and 1 ㅇ $\mathrm{cl} 4.1$ $\mathrm{mm}$; same data as lectotype.

Other material examined. New Caledonia: River Iouanga, $20^{\circ} 41.032^{\prime} \mathrm{S} 164^{\circ} 23.676^{\prime} \mathrm{E}, \mathrm{MNHN}-\mathrm{IU}-$ 2018-216, 1 q ovig. cl 4.2 mm; coll. V. de Mazancourt, 9.xi.2016; River Hienghène: MNHN-IU-2018-217, 1ठ cl 3.7 mm (DNA: CA1726), 2044.058'S 16454.061'E, coll. V. de Mazancourt, 14.xi.2016; River Dumbea, altitude $4 \mathrm{~m}, 22^{\circ} 08.332^{\prime} \mathrm{S} 166^{\circ} 28.013^{\prime} \mathrm{E}, \mathrm{MNHN}-\mathrm{IU}-2018-218,1$, ovig. cl $4.0 \mathrm{~mm}, \mathrm{MNHN}-\mathrm{IU}-2018-219$,

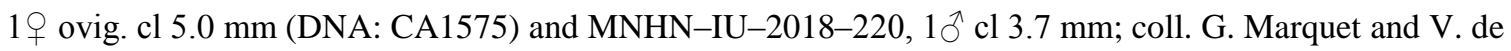
Mazancourt, 16.xi.2016; River La Foa, altitude 6 m, 21³9.051'S 16555.202'E, MNHN-IU-2018-221, 1 ㅇ ovig. cl 5.6 mm and MNHN-IU-2018-222, 1 q ovig. cl 6.5 mm (DNA: CA1610), coll. G. Marquet and V. de Mazancourt, 27.xi.2016; River Courrie, altitude 6 m, 21ํ34.676'S 165²9.716'E, MNHN-IU-2018-223, 1 우 ovig. cl 5.3 mm (DNA: CA1621); coll. G. Marquet and V. de Mazancourt, 28.xi.2016; River Coula, altitude 240 $\mathrm{m}, 21^{\circ} 21.656^{\prime} \mathrm{S} 165^{\circ} 20.370^{\prime} \mathrm{E}, \mathrm{MNHN}-\mathrm{IU}-2018-224,1 \delta^{\jmath} \mathrm{cl} 4.3 \mathrm{~mm}$; coll. G. Marquet and V. de Mazancourt, 
Publisher: CSIRO; Journal: IS:Invertebrate Systematics

\section{Article Type: Research Paper; Volume: ; Issue: ; Article ID: IS18034}

DOI: 10.1071/IS18034; TOC Head:

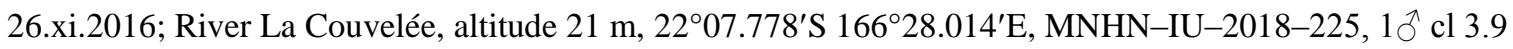

mm, coll. G. Marquet and V. de Mazancourt, 16.xi.2016.

C. nilotica var. gracilipes. NMB 1061h, $10 \hat{\text { cl }} 3.7$ mm; River La Foa, coll. F. Sarasin and J. Roux, 16.i.1912; NMB 1061 g, 1 q ovig. cl 4.5 mm, 2q cl 3.6-4.4 mm and 2ð cl 2.9-3.4 mm; Koné, coll. Sarasin and Roux, 9.viii.1911.

Caridina wyckii var. gracilipes De Man, 1892 New Caledonia: BPBM S5060, 1 q cl 4.2 mm, coll. F. X. Williams, 1940.

Comparative material. Caridina brachydactyla De Man, 1908.

Type material. Indonesia: Caridina nilotica var. brachydactyla De Man, 1908.

Lectotype. Indonesia: Flores Island: river near Reo, RMNH.CRUS.D.977, 1 + ovig cl 4.8 mm; coll. M. Weber.

Paralectotypes. $\quad$ Indonesia: Sulawesi: Luwu: river near Palopo, RMNH.CRUS.D.2552, 2 + ovig cl 5.3$5.4 \mathrm{~mm}$, coll. M. Weber.

Other material. Indonesia: Bali: C. brachydactyla: NMB 1054a, 1 cl 5.8 mm (DNA: CA037); coll. P. Wirz, 1926; WK 63-10, $2 \widehat{\jmath} \mathrm{cl} 2.7 \mathrm{~mm}$ (DNA: CA1129) and $3.7 \mathrm{~mm}$ (DNA: CA1130) 1 + ovig cl $4.3 \mathrm{~mm}$ and

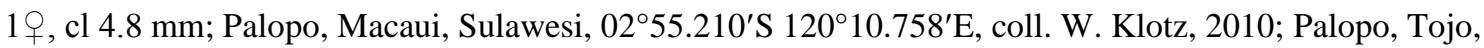
Sulawesi, WK 64-10-3 1 q ovig cl 4.0 mm (DNA: CA1131), coll. W. Klotz, 2010.

Caridina nilotica var. meridionalis. Australia: Cari Creek: Cook Town: N. Queensland, NMB 1054d, $1 \widehat{\jmath} \mathrm{cl} 4.7 \mathrm{~mm}, 1$ q ovig $\mathrm{cl} 5.6 \mathrm{~mm}$ and 2 q $\mathrm{cl} 5.8-6.5 \mathrm{~mm} ; 1923$.

\section{Diagnosis}

Carapace (Fig. $7 G, N, O)$ : smooth, glabrous, with sharp antennal spine placed at lower orbital angle.

Pterygostomian margin blunt. Rostrum variable, 0.8-2.1 of $\mathrm{cl}$, reaching sometimes well beyond scaphocerite; 16-26 dorsal teeth, leaving distally unarmed part of rostrum 0.8-2.1 times that of armed part, except for 1-3 subapical teeth, 1-3 post-orbital teeth; 5-33 teeth on the ventral margin extending from proximal end either to tip or with short distal part unarmed. Number of dorsal teeth on the rostrum behind the first ventral tooth 10-15. Rostral formula: (1-3) 16-26 + 1-3 / 5-33.

First pereiopod (Fig. 7A): slender, chela 2.0-2.7 times as long as wide, dactylus 2.8-46 times as long as wide, 1.1-1.7 length of palm; carpus 2.3-3.5 times as long as wide with shallow excavation on anterior margin.

Second pereiopod (Fig. 7B): more slender and longer than first pereiopod; chela 2.1-3.4 times as long as wide, dactylus 3.5-5.7 times as long as wide, 1.2-1.9 times length of palm; carpus 4.1-6.2 times as long as wide. 
Publisher: CSIRO; Journal: IS:Invertebrate Systematics

Article Type: Research Paper; Volume: ; Issue: ; Article ID: IS18034

DOI: 10.1071/IS18034; TOC Head:

Third pereiopod (Fig. 7C, D): dactylus 3.2-4.3 times as long as wide, terminal spine included, with 6-9 spines on flexor margin in addition to the terminal one; propodus 12.4-19.8 times as long as wide, 3.9-5.8 times as long as dactylus.

Fifth pereiopod (Fig. 7E, F): dactylus 4.4-6.6 times as long as wide with 42-58 spiniform setae on flexor margin; propodus 15.3-22.7 times as long as wide, 3.2-5.3 times as long as dactylus.

Telson (Fig. 7M): variable, mostly rounded without a median process, rarely triangular with a median process; 3-4 pairs of distal simple setae, intermediate setae slightly shorter or slightly longer than the lateral setae.

Pre-anal carina (Fig. 7I): armed with a spine.

First male pleopod (Fig. 7K): leaf-like endopod with well-developed appendix interna.

Second male pleopod (Fig. $7 L$ ): appendix masculina on second pleopod reaching 0.56 times length of endopod; appendix interna reaching 0.85 times length of appendix masculina.

Uropodal diaeresis (Fig. 7H): with 7-13 spinules.

Eggs (Fig. 7J): size $0.34-0.75 \times 0.24-0.48 \mathrm{~mm}$.

\section{Colour pattern}

Colour varies in live specimens and tends to match their background. The colour of the body is hyaline with many red dots. The colouration is lost on preserved material (Fig. 8G, $H$ ).

\section{Distribution}

Caridina meridionalis is endemic to New Caledonia (Roux 1926a; present study) (Fig. 2).

\section{Habitat}

All specimens were collected in rivers, from the estuary in brackish water to the upper middle course in freshwater.

\section{Remarks}

Our specimens of $C$. meridionalis agree with those of Richard and Clark (2014) in accordance with the slender rostrum, length $0.8-2.1$ times length of the carapace (vs $0.75-1$ by Richard and Clark 2014); with 16-26 dorsal teeth (vs 11-27 by Richard and Clark 2014) and 5-33 ventral teeth (vs 4-17 by Richard \& Clark 2014); P1 carpus 2.3-3.5 (vs 1.8-2.4 by Richard and Clark 2014); P2 carpus 4.16.2 (vs 4.5-5.5 by Richard and Clark 2014); P3 propodus 3.9-5.8 times as long as dactylus (vs 5.07.0 by Richard and Clark 2014); P5 dactylus 4.4-6.6 times long as wide (vs 2-4.2 by Richard and Clark 2014) with 42-62 spiniform setae (vs 45-60 by Richard and Clark 2014); larger eggs 0.34-0.75 $\times 0.24-0.48 \mathrm{~mm}$ (vs $0.60-0.65 \times 0.35-0.43 \mathrm{~mm}$ by Richard and Clark 2014); pre-anal carina with a spine and diaeresis with 7-13 spinules (vs 9-14 by Richard and Clark 2014). 
Publisher: CSIRO; Journal: IS:Invertebrate Systematics

Article Type: Research Paper; Volume: ; Issue: ; Article ID: IS18034

DOI: 10.1071/IS18034; TOC Head:

Jean Roux (1926b) described C. meridionalis from Australia. Agreeing with Richard and Clark (2014), these Australian specimens differ from the type specimens of $C$. meridionalis with respect to the following characters, short P1 carpus, 2.1-2.4 (vs 2.3-3.5 for types); short P3 dactylus, 3.1-3.4 (vs 3.2-4.3 for types); smaller eggs, $0.40-0.43 \times 0.18-0.27 \mathrm{~mm}$ (vs $0.34-0.75 \times 0.24-0.48 \mathrm{~mm}$ for types) and its triangular posterior margin with median process, bearing one pair of long lateral simple setae and two pairs of intermediate simple setae that are shorter than the laterals (vs mostly rounded without a median process rarely triangular with a median process; $3-4$ pairs of distal spiniform setae, intermediate spiniform setae slightly shorter or slightly longer than the lateral spiniform setae). Contrary to Richard and Clark (2014), who considered them to be C. brachydactyla, we identified them as $C$. gracilipes because of their short P1 chela, 2-2.1 (vs 2.1-2.3 in C. brachydactyla); short P2 chela 2.4-2.9 (vs 2.7-3.2 in C. brachydactyla); P3 dactylus with 8-9 spines on the flexor margin in addition to the terminal one (vs 5-7 in C. brachydactyla) and P5 dactylus with 50-67 spiniform setae on the flexor margin (vs 32-42 in C. brachydactyla).

We observed a great variation in egg size (Table 2), with the specimens with the biggest eggs collected at the higher altitudes. This phenomenon has been shown in Paratya australiensis (Hancock 1998) and is supposed to have appeared to maintain the population at higher altitudes, preventing the drift of the larvae down to the sea.

\section{Acknowledgements}

The authors wish to thank Urs Wuest and Edi Stöckli (NMB) for providing syntypes of $C$. brevidactyla from Aru and specimens of $C$. gracilipes from Flores and Sulawesi; Oliver Coleman (ZMB) for providing specimens of $C$. appendiculata from Sulawesi; Paula Martin-Lefèvre and Laure Corbari (MNHN) for providing holotype and paratypes of $C$. longirostris; Charles Fransen and Karen van Dorp (ZMA) for providing lectotype male and syntypes of C. appendiculata; Holly Bollick (BPBM) for loan of specimens of 'C. nilotica complex' from Fiji and José Christopher Escano Mendoza, curator of Crustacea (NSM), for loan of $C$. grandirostris.

Palau and Pohnpei: We would like to thank Brian Lynch, Magalie Castelin, Laura Taillebois and Philippe Gerbeaux for their help collecting specimens in the field. This work was supported by the National Museum of Natural History of Paris, the AIMARA Association and the French Ichthyological Society. We would like to thank the Ministry of Natural Resources, Environment, and Tourism Koror, Republic of Palau, and in particular Helena Rebelkuul from the Bureau of Marine Resources and Kashgar Rengulbai (and his assistant Gwen) from the Bureau of Agriculture (BOAGRI), for their help with processing the research permits. Thanks to the Conservation Society of Pohnpei and particularly Eugene Joseph (Director), Francesca Sohl Obispo, Relio Lengsi and Iakop loans, and the Office of Fisheries and Aquaculture.

Choiseul, Kolobangara and Vella Lavella: We would like to thank David Boseto, Brendan Ebner and Philippe Gerbeaux for their help collecting specimens in the field. The study was made possible by a grant given to the French Ichtyological Society in the context of the 'Critical Ecosystem Partnership Fund (CEPF)' (Melanesia hotspot). The Critical Ecosystem Partnership Fund is a joint initiative of l'Agence Française de Développement, Conservation International, the Global Environment Facility, the Government of Japan, the MacArthur 
Publisher: CSIRO; Journal: IS:Invertebrate Systematics

\section{Article Type: Research Paper; Volume: ; Issue: ; Article ID: IS18034 \\ DOI: 10.1071/IS18034; TOC Head:}

Foundation and the World Bank. A fundamental goal is to ensure civil society is engaged in biodiversity conservation. We would like to acknowledge the customary landowners and tribes of Mount Maetambe to Kolobangara River Watershed, the Lauru Land Conference of Tribal Community, Choiseul Province, villages and tribes of Hunda-Kena, Jack Harbour, Poitete, Lodumoe and Vanga who welcomed us on Kolobangara Island, Vella Lavella villages and the Solomon Islands Government for the support and facilitation of the legal process that have allowed the expedition team to conduct the scientific research.

We would also like to thank KIBCA and ESSI for the meetings in the villages before the expeditions and for the organisation of the trip.

Vanuatu: We would like to thank Clara Lord, Donna Kalfatak and Gilles Segura for their help collecting specimens in the field. We would like to acknowledge the Department of Environmental Protection and Conservation (DEPC) for providing us the research permit. We thank the TAFEA Province Secretary General, the Aneityum provincial area secretary, Ruben Niriam and the Tanna provincial area secretaries. We are particularly grateful to Chief Simon Nijina (Analcahat Chief) and with Chief Jack Nipveae (Secretary for the Nelvou Aneityum Council of Chiefs), to Chief Samson on Green Hill and Bob Kev (Green Hill school headmaster and contact person for the Nusumetu Conservation Area) and his sister Marie Kev (teacher at Green Hill School and also assists with a lot of field work within the Conservation area) and to the local communities who allowed us to prospect the rivers. Thanks to Philippe Bouchet and the program 'Our Planet Reviewed' for the expedition Santo 2006.

New Caledonia: We would like to thank Joel Delafenêtre, Clementine Flouhr and Pascal Tiberghien for their help collecting specimens in the field. The work was supported by a convention between OEIL and South Province of New Caledonia. We would like to thank Jean-Jérôme Cassan (North Province) and Damien Grima (South Province) for providing the research permit. Special thanks to Florence and Jean-Pierre Cabée, and Marie and Claude Hugon for their hospitality. Thanks to the OEIL staff (Fabien Albouy, Adrien Bertaud, Deiphine Bossy and Matthieu Juncker (Director)). 'Our Planet Reviewed' - New Caledonia expedition (2016-2019) is a joint project of MNHN and Conservatoire d'Espaces Naturels (CEN) de Nouvelle-Calédonie. It is/was funded mainly by the Gouvernement de la Nouvelle-Calédonie, Province Sud and Province Nord, and Office des Postes et Télécommunications (OPT) and in-kind support from AirCalin and Toyota Nouvelle-Calédonie. The expedition operated under permits issued by the Direction de l'Environnement (DENV) of Province Sud and Direction du Développement Economique et de l'Environnement (DDEE) of Province Nord. Our Planet Reviewed / La Planète Revisitée is a global initiative founded in 2007 by Muséum National d'Histoire Naturelle (MNHN) and Pro-Natura Interational (PNI).

Australia: Thanks to Benjamin Mos for collecting and sending us specimens and the authorities that provided the sampling permits.

Taiwan: We thank Nathan Chiang (Taipei) for his great support during the field trip of the second author to Taiwan.

Thanks to the Service de Systématique Moléculaire of the MNHN and its staff for allowing us to perform the molecular work. 
Publisher: CSIRO; Journal: IS:Invertebrate Systematics

Article Type: Research Paper; Volume: ; Issue: ; Article ID: IS18034 DOI: 10.1071/IS18034; TOC Head:

\section{References}

$<$ jrn>Barthélemy, C.-J. (1834). Sur M. P. Roux. Notice nécrologique. Annales de la Société Entomologique de France 3, xliv-li. $</$ jrn $>$

<jrn>Bouvier, E. L. (1905). Observations nouvelles sur les crevettes de la famille des Atyidés. Bulletin Scientifique de la France et de la Belgique 39, 57-134.</jrn>

<bok>Bouvier, E. L. (1925). 'Recherches sur la Morphologie, les Variations, la Distribution Géographique des Crevettes de la Famille des Atyidés.' (Encyclopédie Entomologique de Roret: Paris, France.)</bok>

<edb>Cai, Y. (2014). Atyid shrimps of Hainan Island, southern China, with the description of a new species of Caridina (Crustacea, Decapoda, Atyidae). In 'Advances in Freshwater Decapod Systematics and Biology' (Eds D.C. Yeo, N. Cumberlidge and S. Klaus) Crustaceana Monographs 19, pp. 207-231. (Brill: Leiden, Netherlands.) doi:10.1163/9789004207615 013</edb>

$<$ jrn>Cai, Y., and Anker, A. (2004). On a collection of freshwater shrimps (Crustacea; Decapoda; Caridea) from the Philippines, with descriptions of five new species. Tropical Zoology 17, 233-266. doi:10.1080/03946975.2004.10531207</jrn>

$<$ jrn>Cai, Y., and Ng, P. K. L. (1999). A revision of the Caridina serrata species group, with descriptions of five new species (Crustacea: Decapoda: Caridea: Atyidae). Journal of Natural History 33, 1603-1638. doi:10.1080/002229399299789</jrn>

$<\mathrm{jrn}>$ Cai, Y., and Ng, P. K. L. (2001). The freshwater decapod crustaceans of Halmahera, Indonesia. Journal of Crustacean Biology 21(3), 665-695. doi:10.1163/20021975-99990167</jrn>

<jrn>Cai, Y., and Ng, P. K. L. (2007a). A revision of the Caridina gracilirostris De Man, 1892, species group, with descriptions of two new taxa (Decapoda; Caridea; Atyidae). Journal of Natural History 41(25-28), 1585-1602. doi:10.1080/00222930701458754</jrn>

$<$ jrn>Cai, Y., and Ng, P. K. L. (2007b). The freshwater and terrestrial decapod crustacea of Pulau Tioman, Peninsular Malaysia. The Raffles Bulletin of Zoology 6, 197-244.</jrn>

$<$ jrn>Cai, Y., and Shokita, S. (2006). Report on a collection of freshwater shrimps (Crustacea: Decapoda:

Caridea) from the Philippines, with descriptions of four new species. The Raffles Bulletin of Zoology 54(2), 245-270.</jrn>

<jrn>Cai, Y., Ng, P. K. L., Shokita, S., and Satake, K. (2006). On the species of Japanese atyid shrimps

(Decapoda: Caridea) described by William Stimpson (1860). Journal of Crustacean Biology 26(3), 392-419. doi:10.1651/C-2572.1</jrn>

$<$ jrn>Cai, Y., Choy, S., and Ng, P. K. L. (2009). Epigean and hypogean freshwater shrimps of Bohol Island, central Philippines (Crustacea: Decapoda: Caridea). The Raffles Bulletin of Zoology 57(1), 65-89.</jrn>

$<$ jrn>Chace, F. A., Jr (1997). The caridean shrimps (Crustacea: Decapoda) of the Albatross Philippine

Expedition 1907-1910, Part 6: superfamily Palaemonoidea. Smithsonian Contributions to Zoology 543, 1152. $</ \mathrm{jrn}>$ 
Publisher: CSIRO; Journal: IS:Invertebrate Systematics

Article Type: Research Paper; Volume: ; Issue: ; Article ID: IS18034

DOI: 10.1071/IS18034; TOC Head:

$<$ jrn>Choy, S. C. (1991). The atyid shrimps of Fiji with descriptions of a new species. Zoölogische

Mededeelingen 65, 342-343.</jrn>

<edb>Choy, S. C., and Marquet, G. (2002). Biodiversity and zoogeography of atyid shrimps (Crustacea:

Decapoda: Natantia) of New Caledonia. In 'Zoologia Neocaledonica 5. Systématique et Endémisme en

Nouvelle-Calédonie'. (Eds J. Najt and P. Grandcolas.) pp. 223-231. (Mémoires du Muséum national

d'Histoire naturelle: Paris, France.) $</$ edb $>$

<jrn>Coleman, C. O. (2003). 'Digital inking': how to make perfect line drawings on computers. Organisms, Diversity \& Evolution 3(4), 303-304. doi:10.1078/1439-6092-00081</jrn>

$<$ jrn>Coleman, C. O. (2006). Substituting time-consuming pencil drawings in arthropod taxonomy using stacks of digital photographs. Zootaxa 1360, 61-68.</jrn>

<edb>Cook, B. D., Page, T. J., \& Hughes, J. M. (2011). Molecular and conservation biogeography of freshwater caridean shrimps in north-western Australia. In 'Phylogeography and population genetics in Crustacea.' (Eds C. Held, S. Koenemann and C. D. Schubart) pp. 273-287 (Taylor and Francis Group: Boca Raton, FL, USA). $</ e d b>$

<jrn>Covich, A. P., Palmer, M. A., and Crowl, T. A. (1999). The role of benthic invertebrate species in freshwater ecosystems. Bioscience 49, 119-128. doi:10.2307/1313537</jrn>

<jrn>Darriba, D., Taboada, G. L., Doallo, R., and Posada, D. (2012). jModelTest 2: more models, new heuristics and parallel computing. Nature Methods 9(8), 772. doi:10.1038/nmeth.2109</jrn>

<jrn>De Grave, S., Smith, K. G., Adeler, N. A., Allen, D. J., Alvarez, F., Anker, A., Cai, Y., Carrizo, S. F.,

Klotz, W., Mantelatto, F. L., Page, T. J., Shy, J.-Y., Villalobos, J. L., and Wowor, D. (2015). Dead shrimp blues: a global assessment of extinction risk in freshwater shrimps (Crustacea: Decapoda: Caridea). PLoS

One 10, e0120198. doi:10.1371/journal.pone.0120198</jrn>

<edb>De Man, J. G. (1892). Decapoden des Indischen Archipels. In 'Zoologische Ergebnisse einer Reise in Niederländisch Ost-Indien Vol. 2'. (Ed. M. Weber.) pp. 265-527. (E.J. Brill: Leiden, Netherlands.)</edb> $<$ jrn>De Man, J. G. (1908). On Caridina nilotica (Roux) and its varieties. Records of the Indian Museum 2 (part 3, n. 28), 253-283.</jrn>

<jrn>de Mazancourt, V., Marquet, G., and Keith, P. (2017). The 'Pinocchio-shrimp effect': first evidence of rostrum length variation with the environment in Caridina (Crustacea: Decapoda: Atyidae). Journal of Crustacean Biology 37(3), 249-257.</jrn>

<jrn>de Mazancourt, V., Marquet, G., Rogers, D. C., and Keith, P. (2018). Description of a new species of Caridina (Crustacea: Decapoda: Atyidae) from two Micronesian islands (Guam and Babeldaob). Zootaxa 4377(1), 39-50. doi:10.11646/zootaxa.4377.1.3</jrn>

<jrn>de Mazancourt, V., Castelin, M., Renneville, C., Mlambo, M. C., Marquet, G., and Keith, P. (in press). Revalidation of Caridina natalensis De Man, 1908 (Crustacea: Decapoda: Atyidae) in the South Western Indian Ocean. Zootaxa. 
Publisher: CSIRO; Journal: IS:Invertebrate Systematics

Article Type: Research Paper; Volume: ; Issue: ; Article ID: IS18034

DOI: 10.1071/IS18034; TOC Head:

$<$ jrn>Edgar, R. C. (2004). MUSCLE: multiple sequence alignment with high accuracy and high throughput.

Nucleic Acids Research 32, 1792-1797. doi:10.1093/nar/gkh340</jrn>

<other>Edmondson, C. H. (1935). Atyidae of southern Polynesia. Occasional Papers of Bernice P. Bishop

Museum 10(24), 3-40.</other>

$<$ jrn>Felsenstein, J. (1985). Confidence limits on phylogenies: an approach using the bootstrap. Evolution 39,

783-791. doi:10.1111/j.1558-5646.1985.tb00420.x</jrn>

<jrn>Guindon, S., and Gascuel, O. (2003). A simple, fast and accurate method to estimate large phylogenies by maximum-likelihood. Systematic Biology 52, 696-704. doi:10.1080/10635150390235520</jrn>

<jrn>Han, C. C., Chang, C. S., Cheng, I. M., Fang, L. S., and Tew, K. S. (2011). Population dynamics of a landlock and amphidromous freshwater shrimp, Caridina gracilipes (Decapoda: Caridea) in subtropical waters. Journal of Crustacean Biology 31(2), 278-285. doi:10.1651/10-3331.1</jrn>

<jrn>Hancock, M. A. (1998). The relationship between egg size and embryonic and larval development in the freshwater shrimp Paratya australiensis Kemp (Decapoda: Atyidae). Freshwater Biology 39, 715-723. doi:10.1046/j.1365-2427.1998.00323.x $</ j r n>$

<jrn>Holthuis, L. B. (1965). The Atyidae of Madagascar. Mémoires du Muséum National d'Histoire Naturelle, Série A (Zoologie) 33, 1-48.</jrn>

$<$ jrn>Holthuis, L. B. (1969). Etudes hydrobiologiques en Nouvelle-Calédonie (Mission 1965 du Premier institut de Zoologie de l'Université de Vienne). IX. The freshwater shrimps of New Caledonia. Cahiers O.R.S.T.O.M. Série Hydrobiologie 3(2), 87-108.</jrn>

$<$ jrn> Holthuis, L. B. (1978). A collection of decapod Crustacea from Sumba, Lesser Sunda Islands, Indonesia. Zoologische Verhandelingen Uitgegeven door het Rijksmuseum van Natuurlijke Historie te Leiden 53(19), 209-224.</jrn>

<jrn>Hung, M. S., Chan, T. Y., and Yu, H. P. (1993). Atyid shrimps (Decapoda; Caridea) of Taiwan, with descriptions of three new species. Journal of Crustacean Biology 13(3), 481-503.

doi: $10.2307 / 1548789</ j r n>$

<conf>Jalihal, D. R., and Shenoy, S. (1998). Taxonomic revision of some Indian prawn species of genus

Caridina H. Milne Edwards, 1837 (Atyidae). In 'Proceedings and Abstracts of the Fourth International

Crustacean Congress'. 128-129.</conf >

<jrn>Jugovic, J., Prevorcnik, S., Aljancic, G., and Sket, B. (2010). The atyid shrimp (Crustacea: Decapoda:

Atyidae) rostrum: phylogeny versus adaptation, taxonomy versus trophic ecology. Journal of Natural History

44, 2509-2533. doi:10.1080/00222933.2010.502258</jrn>

<bok>Karge, A., and Klotz, W. (2007). 'Süßwassergarnelen aus Aller Welt.' (Dähne Verlag: Etllingen,

Germany.) $</$ bok>

<jrn>Kearse, M., Moir, R., Wilson, A., Stones-Havas, S., Cheung, M., Sturrock, S., Buxton, S., Cooper, A.,

Markowitz, S., Duran, C., Thierer, T., Ashton, B., Mentjies, P., \& Drummond, A. (2012). Geneious Basic: an 
Publisher: CSIRO; Journal: IS:Invertebrate Systematics

Article Type: Research Paper; Volume: ; Issue: ; Article ID: IS18034

DOI: 10.1071/IS18034; TOC Head:

integrated and extendable desktop software platform for the organization and analysis of sequence

data.Bioinformatics, 28(12), 1647-1649.</jrn>

<bok>Keith, P., and Marquet, G. (2011). 'Poissons et Crustacés d'Eau Douce de Wallis et de Futuna.' (Société

Française d'Ichtyologie: Paris, France.) $<$ /bok>

<bok>Keith, P., Marquet, G., Valade, P., Bosc, P., and Vigneux, E. (2006). 'Atlas des Poissons et des Crustacés

d'Eau Douce des Comores, Mascareignes et Seychelles.' (Patrimoines Naturels: MNHN, Paris,

France. $)</$ bok $>$

<bok>Keith, P., Marquet, G., Lord, C., Kalfatak, D., and Vigneux, E. (2010). 'Poissons et Crustacés d'Eau

Douce du Vanuatu.' (Société Française d'Ichtyologie: Paris, France.)</bok>

<bok>Keith, P., Marquet, G., Gerbeaux, P., Vigneux, E., and Lord, C. (2013). 'Poissons et Crustacés d'Eau

Douce de Polynésie. Taxonomie, Écologie, Biologie et Gestion.' (Société Française d’Ichtyologie: Paris,

France. $)</$ bok $>$

$<$ jrn $>$ Kemp, S. (1918). Zoological results of a tour in the Far East. Crustacea Decapoda and Stomatopoda.

Memoirs of the Royal Asiatic Society of Bengal 6, 274-293.</jrn>

<jrn>Klotz, W., Karge, A., and von Rintelen, K. (2007). A redescription of two atyid shrimps (Decapoda:

Caridina) from central Sulawesi, Indonesia. Zootaxa 1466, 1-10.</jrn>

<jrn>Kumar, S., Stetcher, G., and Tamura, K. (2016). MEGA7: molecular evolutionary genetics analysis

version 7.0 for bigger datasets. Molecular Biology and Evolution 33(7), 1870-1874.

doi:10.1093/molbev/msw054</jrn>

<jrn>Leberer, T., and Nelson, S. G. (2001). Factors affecting the distribution of atyid shrimps in two tropical

insular rivers. Pacific Science 55, 389-398. doi:10.1353/psc.2001.0035</jrn>

<jrn>Li, S.-Q., and Liang, X.-Q. (2002). Caridean prawns of northern Vietnam (Decapoda: Atyidae,

Palaemonidae). Dong Wu Fen Lei Xue Bao 27, 707-716. </jrn>

<edb>Liang, X.-Q. (2004). Crustacea Decapoda Atyidae. In 'Fauna Sinica. Invertebrata Vol. 36'. pp. 1-375.

(Science Press: Bejing, China.) $</$ edb>

<bok>Linant de Bellefonds, M. A. (1843). 'Mémoire sur le Lac Moéris, présenté et lu à la Société Egyptienne le

5 Juillet 1842.' (Société Egyptienne: Alexandrie, Egypt.)</bok>

<jrn>Maciolek, J. A., and Ford, J. I. (1987). Macrofauna and environment of the Nanpil-Kiepw River, Ponape,

Eastern Caroline Islands. Bulletin of Marine Science 41, 623-632.</jrn>

<bok>Marquet, G., Keith, P., and Vigneux, E. (2003). 'Atlas des Poissons et Crustacés d'Eau Douce de la

Nouvelle-Calédonie.' (Patrimoines Naturels: MNHN, Paris, France.)</bok>

<conf>Miller, M. A., Pfeiffer, W., and Schwartz, T. (2010). Creating the CIPRES Science Gateway for

inference of large phylogenetic trees. In 'Proceedings of the Gateway Computing Environments Workshop

(GCE)'. pp. 1-8.</conf> 
Publisher: CSIRO; Journal: IS:Invertebrate Systematics

Article Type: Research Paper; Volume: ; Issue: ; Article ID: IS18034

DOI: 10.1071/IS18034; TOC Head:

<bok>Milne Edwards, H. (1837). 'Histoire Naturelle des Crustacés, Comprenant l'Anatomie, la Physiologie et

la Classification de ces Animaux.' (Encyclopédie de Roret: Paris, France.)</bok>

<jrn>Page, T. J., and Hughes, J. M. (2011). Neither molecular nor morphological data have all the answers; with an example from Macrobrachium (Decapoda: Palaemonidae) from Australia. Zootaxa 2874, 65-68. </jrn>

<jrn>Page, T. J., Choy, S., and Hughes, J. M. (2005). The taxonomic feedback loop: symbiosis of morphology and molecules. Biology Letters 1, 139-142. doi:10.1098/rsbl.2005.0298</jrn>

<jrn>Page, T. J., von Rintelen, K., and Hughes, J. M. (2007). An island in the stream: Australia's place in the cosmopolitan world of Indo-West Pacific freshwater shrimp (Decapoda: Atyidae: Caridina). Molecular Phylogenetics and Evolution 43, 645-659. doi:10.1016/j.ympev.2006.08.007</jrn>

<edb>Palumbi, S. R. (1996). Nucleic acids II: the polymerase chain reaction. In 'Molecular Systematics'. (Eds

D. M. Hillis, B. K. Mable and C. Moritz.) pp. 205-247 (Sinauer Associates: Sunderland, MA, USA.)</edb>

<jrn>Pringle, C. M., Blake, G. A., Covich, A. P., Buzby, K. M., and Finley, A. (1993). Effects of omnivorous

shrimp in a montane tropical stream: sediment removal, disturbance of sessile invertebrates and enhancement

of understory algal biomass. Oecologia 93, 1-11. doi:10.1007/BF00321183 </jrn>

<jrn>Richard, J., and Clark, P. F. (2005). Caridina nilotica (P. Roux, 1833) (Crustacea: Decapoda: Caridea:

Atyidae) from East Africa, with descriptions of four new species. Proceedings of the Biological Society of

Washington 118(4), 706-730. doi:10.2988/0006-324X(2005)118[706:CNPRCD]2.0.CO;2</jrn>

<jrn>Richard, J., and Clark, P. F. (2009). African Caridina (Crustacea: Decapoda: Caridea: Atyidae):

redescriptions of C. africana Kingsley, 1882, C. togoensis Hilgendorf, 1893, C. natalensis Bouvier, 1925 and

C. roubaudi Bouvier, 1925 with descriptions of 14 new species. Zootaxa 1995, 1-75.</jrn>

<jrn>Richard, J., and Clark, P. F. (2010). Caridina H. Milne Edwards, 1837 (Crustacea: Decapoda: Caridea:

Atyoidea; Atyidae) frehwater shrimps from eastern and southern Africa. Zootaxa 2372, 305-337.</jrn>

<jrn>Richard, J., and Clark, P. F. (2014). Caridina simoni Bouvier, 1904 (Crustacea: Decapoda: Caridea:

Atyoidea: Atyidae) and the synonymy by Johnson, 1963. Zootaxa 3841, 301-338.

doi:10.11646/zootaxa.3841.3.1 </jrn>

<jrn>Ronquist, F., and Huelsenbeck, J. P. (2003). MrBayes 3: Bayesian phylogenetic inference under mixed models. Bioinformatics 19, 1572-1574. doi:10.1093/bioinformatics/btg180</jrn>

$<$ jrn>Roux, J. L. F. P. (1833). Lettre relative à divers Coquilles, Crustacés. Insectes, Reptiles et Oiseaux, observés en Égypte; adressée par M. Roux à M. le Baron de Férussac. Annales des Sciences Naturelles 28, 72-78. $<$ jirn>

<jrn>Roux, J. L. F. P. (1834). Lettre de M. Polydore Roux adressée à M. le Baron de Férussac et datée de Bombay, 15 juin 1832. Annales des Sciences Naturelles, Série 2. Zoologie 2, 99-104.</jrn>

<bok>Roux, P.-M. (1834). 'Éloge Historique de Polydore Roux Conservateur du Cabinet d'Histoire Naturelle de la Ville de Marseille, Member de Plusieurs Sociétés Savantes Nationales et Étrangères.' (Muséum d'histoire naturelle de Marseille: Marseille, France). $<$ /bok> 
Publisher: CSIRO; Journal: IS:Invertebrate Systematics

Article Type: Research Paper; Volume: ; Issue: ; Article ID: IS18034

DOI: 10.1071/IS18034; TOC Head:

$<$ jrn>Roux, J. (1920). Süsswasserdekapoden von den Aru-und Kei-Inseln. Abhandlungen der

Senckenbergischen Naturforschenden Gesellschaft 35, 317-351.</jrn>

<edb>Roux, J. (1926a). Crustacés décapodes d'eau douce de la Nouvelle-Calédonie. In 'Nova Caledonia, 4(2)'.

(Eds F. Sarasin and J. Roux.) pp. 181-240. (C.W. Kreidel’s Verlag: Munich, Germany.)</edb>

<jrn>Roux, J. (1926b). An account of Australian Atyidae. Records of the Australian Museum 15, $237-254$.

doi:10.3853/j.0067-1975.15.1926.812</jrn>

$<$ jrn $>$ Schenkel, E. (1902). Beitrag zur Kenntnis der dekapodenfauna von Celebes. Verhandlungen der

Natuurforschenden Gesellschaft in Basel 13, 485-585.</jrn>

<bok>Short, J. W. (2009). 'Freshwater Crustacea of the Mimika Region - New Guinea.' (PT Freeport: South

Jakarta, Indonesia.) $<$ /bok $>$

<bok>Shy, J. Y., and Yu, H. P. (1998). 'Freshwater Shrimps of Taiwan.' (National Museum of Marine Biology and Aquarium Press: Checheng, Taiwan.)</bok>

<jrn>Stamatakis, A. (2014). RAxML version 8: a tool for phylogenetic analysis and post-analysis of large phylogenies. Bioinformatics, 30(9), 1312-1313. doi:10.1093/bioinformatics/btu033</jrn>

<jrn>Stimpson, W. (1860). Prodromus descriptionis animalium evertebratorum, quae in Expeditione ad

Oceanum Pacificum Septentrionalem, a Republic Federata missa, Cadwaladore Ringgold et Johanne Rodgers Ducibus, observavit et descripsit. Pars VIII, Crustacea Macrura. Proceedings. Academy of Natural Sciences of Philadelphia 1860, 22-47. </jrn>

$<$ jrn>Ueno, M. (1935). Inland water fauna of Formosa. I. Crustacea Decapoda. Transactions of the Natural History Society of Formosa 25, 270-276. </jrn>

<jrn>von Rintelen, K., and Cai, Y. (2009). Radiation of endemic species flocks in ancient lakes: systematic revision of the freshwater shrimp Caridina H. Milne Edwards, 1837 (Crustacea: Decapoda: Atyidae) from the ancient lakes of Sulawesi, Indonesia, with the description of eight new species. The Raffles Bulletin of Zoology 57, 343-452.</jrn>

<jrn>von Rintelen, K., Page, T. J., Cai, Y., Roe, K., Stelbrink, B., Kuhajda, B. R., Iliffe, T. M., Hughes, J., and von Rintelen, T. (2012). Drawn to the dark side: a molecular phylogeny of freshwater shrimps (Crustacea: Decapoda: Caridea: Atyidae) reveals frequent cave invasions and challenges current taxonomic hypotheses. Molecular Phylogenetics and Evolution 63(1), 82-96. doi:10.1016/j.ympev.2011.12.015</jrn>

<edb>Wowor, D., Cai, Y., and Ng, P. K. L. (2004). Crustacea: Decapoda, Caridea. In 'The Freshwater Invertebrates of the Malaysian Region'. (Eds C. M. Yule and Y. H. Sen.) pp. 337-357. (Malaysian Academy of Sciences: Kuala Lumpur, Malaysia. $)\langle/ e d b>$

<jrn>Xu, G., Du, F., Nie, Z., Xu, P., and Gu, R. (2016). Complete mitochondrial genome of Caridina nilotica gracilipes. Mitochondrial DNA. Part A, DNA Mapping, Sequencing, and Analysis 27(2), 1249-1250.</jrn>

$<j r n>Y u$, H. P. (1974). On the Atyid shrimps (Crustacea, Decapoda, Atyidae) from Taiwan. Aquaculture 2, 49-

58. $</ \mathrm{jrn}>$ 
Publisher: CSIRO; Journal: IS:Invertebrate Systematics

Article Type: Research Paper; Volume: ; Issue: ; Article ID: IS18034

DOI: 10.1071/IS18034; TOC Head:

Handling editor: Shane Ahyong

Fig. 1. Bayesian $16 \mathrm{~S}$ rRNA phylogenetic tree showing the relationships of some of the species discussed in this study. Numbers above branches indicate Bayesian posterior probabilities; numbers under branches indicate maximum likelihood bootstrap values.

Fig. 2. Distribution map of the five species re-described in this study. Shapes marked with a dot indicate type localities. For Caridina longirostris H. Milne Edwards, 1837, the dashed star indicates the previously accepted type locality; the full star indicates the new proposed type locality.

Fig. 3. Caridina longirostris H. Milne Edwards, 1837: $(A)$ first pereiopod; $(B)$ second pereiopod; $(C)$ third pereiopod; $(D)$ dactylus of third pereiopod; $(E)$ fifth pereiopod; $(F)$ dactylus of fifth pereiopod; $(G)$ anterior region of cephalothorax; $(H)$ uropodal diaeresis; $(I)$ pre-anal carina; $(J)$ eggs; $(K)$ first male pleopod; $(L)$ second male pleopod; $(M)$ telson.

Fig. 4. Caridina appendiculata Jalihal \& Shenoy, 1998: $(A)$ first pereiopod; $(B)$ second pereiopod; $(C)$ third pereiopod; $(D)$ dactylus of third pereiopod; $(E)$ fifth pereiopod; $(F)$ dactylus of fifth pereiopod; $(G)$ anterior region of cephalothorax; $(H)$ uropodal diaeresis; $(I)$ pre-anal carina; $(J)$ eggs; $(K)$ first male pleopod; $(L)$ second male pleopod; $(M)$ telson; $(N, O)$ rostrum variations.

Fig. 5. Caridina brevidactyla Roux, 1920: $(A)$ first pereiopod; $(B)$ second pereiopod; $(C)$ third pereiopod; $(D)$ dactylus of third pereiopod; $(E)$ fifth pereiopod; $(F)$ dactylus of fifth pereiopod; $(G)$ anterior region of cephalothorax; $(H)$ uropodal diaeresis; $(I)$ pre-anal carina; $(J)$ eggs; $(K)$ first male pleopod; $(L)$ second male pleopod; $(M)$ telson; $(N, O)$ rostrum variations.

Fig. 6. Caridina gracilipes De Man, 1892: $(A)$ first pereiopod; $(B)$ second pereiopod; $(C)$ third pereiopod; $(D)$ dactylus of third pereiopod; $(E)$ fifth pereiopod; $(F)$ dactylus of fifth pereiopod; $(G)$ anterior region of cephalothorax; $(H)$ uropodal diaeresis; $(I)$ pre-anal carina; $(J)$ eggs; $(K)$ first male pleopod; $(L)$ second male pleopod; $(M)$ telson; $(N, O)$ rostrum variations.

Fig. 7. Caridina meridionalis Roux, 1926: $(A)$ first pereiopod; $(B)$ second pereiopod; $(C)$ third pereiopod; $(D)$ dactylus of third pereiopod; $(E)$ fifth pereiopod; $(F)$ dactylus of fifth pereiopod; $(G)$ anterior region of cephalothorax; $(H)$ uropodal diaeresis; $(I)$ pre-anal carina; $(J)$ eggs; $(K)$ first male pleopod; $(L)$ second male pleopod; $(M)$ telson; $(N, O)$ rostrum variations.

Fig. 8. Views of live specimens showing their colouration: $(A, B)$ Caridina appendiculata Jalihal \& Shenoy, 1998; (C, D) C. brevidactyla Roux, 1920; $(E, F)$ C. gracilipes De Man, 1892; $(G, H) C$. meridionalis Roux, 1926. Credits: Philippe Keith $(A, B, C)$; Valentin de Mazancourt $(D, G, H)$; Werner Klotz $(E, F)$.

Table 1. List of the Caridina specimens used in the genetic study

\begin{tabular}{|c|c|c|c|c|c|c|}
\hline Species & Locality & Previous ID & $\begin{array}{l}\text { DNA } \\
\text { voucher }\end{array}$ & Museum no. & GenBank no. & Reference \\
\hline \multirow[t]{4}{*}{ C. appendiculata } & \multirow[t]{4}{*}{ Australia } & \multirow{4}{*}{$\begin{array}{l}\text { C. sp. } \\
\text { indistincta } E\end{array}$} & CA1708 & $\begin{array}{l}\text { MNHN-IU- } \\
2018-126\end{array}$ & MH497543 & This study \\
\hline & & & GU0170 & & AY795051 & $\begin{array}{l}\text { Page et al. } \\
2005\end{array}$ \\
\hline & & & CA1665 & $\begin{array}{l}\text { MNHN-IU- } \\
\text { 2018-121 }\end{array}$ & MH497530 & This study \\
\hline & & & CA1667 & $\begin{array}{l}\text { MNHN-IU- } \\
2018-118\end{array}$ & MH497531 & This study \\
\hline
\end{tabular}


Publisher: CSIRO; Journal: IS:Invertebrate Systematics

Article Type: Research Paper; Volume: ; Issue: ; Article ID: IS18034 DOI: 10.1071/IS18034; TOC Head:

Micronesia

Palau

Solomon

Islands

Vanuatu

C. brachydactyla Bali

Sulawesi

C. brevidactyla Fiji

New

Caledonia

Papua New

Guinea
CA1668

C. sp. indistincta $E$

GUC186

CA1669 MNHN-IU-

CA1670 MNHN-IU-

2018-124

CA1333 MNHN-IU-

2018-129

CA1330 MNHN-IU-

2018-130

CA1021 MNHN-IU-

2018-127

CA1494 MNHN-IU-

2018-135

CA1493 MNHN-IU-

2018-133

CA1216 MNHN-IU-

2018-151

CA1139 MNHN-IU-

2018-152

CA1218 MNHN-IU-

2018-153

CA1219 MNHN-IU-

2018-154

CA1220 MNHN-IU-

2018-155

CA1264 MNHN-IU-

2018-143

CA1268 MNHN-IU-

2018-144

CA1489 MNHN-IU-

2018-140

CA1378 MNHN-IU-

2018-142

CA1259 MNHN-IU-

2018-156

CA1261 MNHN-IU-

2018-157

CA037 NMB 1054a

CA1129 WK 63-10

CA1130 WK 63-101

CA1131 WK 63-10

Topotypical

C. longirostris

CA017

RMNH.CRU

S.D.54674

CA1426 MNHN-IU-

2018-159

CA1785

MNHN-IU-

2018-166

CA1788

MNHN-IU-

2018-167

CA1007

MNHN-IU-

C. nilotica

brevidactyla

C. nilotica

brevidactyla
GUC358

GUC529
MH497532

This study

DQ478526

Page et al. 2007

MH497533 This study

MH497534 This study

MH497517 This study

MH497516 This study

MH497499 This study

MH497525 This study

MH497524 This study

MH497504 This study

MH497503 This study

MH497505 This study

MH497506 This study

MH497507 This study

MH497511 This study

MH497512 This study

MH497523 This study

MH497521 This study

MH497509 This study

MH497510 This study

MH497490 This study

MH497500 This study

MH497501 This study

MH497502 This study

MH497484 This study

MH497522 This study

MH497546 This study

MH497547 This study

MH497498 This study

DQ478539 Page et al.

2007

DQ478540 
Publisher: CSIRO; Journal: IS:Invertebrate Systematics

Article Type: Research Paper; Volume: ; Issue: ; Article ID: IS18034 DOI: 10.1071/IS18034; TOC Head:

Solomon

Islands

C. gracilipes

$?$

Australia

Borneo

Flores

Lombok

Sulawesi

Sri Lanka

Taiwan

C. grandirostris Indonesia

Japan

Taiwan
CA1305 MNHN-IU-

2018-168

CA1345 MNHN-IU2018-172

CA1346 MNHN-IU-

2018-171

CA1940 MNHN-IU-

2018-185

CA1302 MNHN-IU-

2018-175

CA1307 MNHN-IU-

2018-188

CA1232 MNHN-IU

C. nilotica

gracilipes

\section{CA1689 MNHN-IU-}

2018-201

CA1690 MNHN-IU-

2018-202

CA1695 MNHN-IU-

2018-205

CA1700 MNHN-IU-

2018-203

CA1694 MNHN-IU-

2018-199

CA1673 MNHN-IU-

2018-209

CA029 NMB 1061f 1

CA1348 MNHN-IU-

2018-207

CA023 ZMA.CRUS

.D.102635 1

ZMA.CRUS

CA024 .D.102635 2

CA025 ZMA.CRUS

CA025 .D.102635 3

CA027 ZMA.CRUS

D.102635 5

ZMB 29016

CA1825 MNHN-IU-

2018-210

MNHN-IU-

2018-211

CA1826

MNHN-IU-

CA1823 2018-212

CA1674 MNHN-IU-

2018-208

C. GUCKZ

brachydactyla 252

$\begin{array}{ll}\text { CA1893 } & \text { ZRC } \\ & \text { 2004.0530 1 }\end{array}$

$\begin{array}{ll}\text { CA1891 } & \text { ZRC } \\ 2004.05193\end{array}$

$\begin{array}{ll}\text { CA1892 } & \text { ZRC } \\ & 2004.05194\end{array}$

CA1676 MNHN-IU-
MH497514

This study

MH497518 This study

MH497519 This study

MH497558 This study

MH497513 This study

MH497515 This study

MH497508 This study

NC_024751

$\mathrm{Xu}$ et al.

2016

MH497538 This study

MH497539 This study

MH497541 This study

MH497542 This study

MH497540 This study

MH497535 This study

MH497489 This study

MH497520 This study

Paralectotype

MH497485 This study

Paralectotype

MH497486 This study

Paralectotype

Paralectotype

MH497487 This study

MH497488 This study

FN995358

von

Rintelen et al. 2012

MH497549 This study

MH497550 This study

MH497548 This study

MH497536 This study

DQ478528 Page et al.

MH497553 This study

MH497551 This study

MH497552 This study

MH497537 This study 
Publisher: CSIRO; Journal: IS:Invertebrate Systematics

Article Type: Research Paper; Volume: ; Issue: ; Article ID: IS18034 DOI: 10.1071/IS18034; TOC Head:

C. leucosticta Japan

C. meridionalis

New
Caledonia

C.

coulaborensis
2018-195

MNHN-IU-

$\begin{array}{ll}\text { CA1912 } & \text { 2018-229 } \\ \text { MNHN-IU }\end{array}$

CA1913 2018-230

CA1894 ZRC

2004.05302

CA1896 ZRC

2004.05304

CA064 NMB 1057a

2

MNHN-IU-

CA1572 2018-226

CA1573 MNHN-IU-

2018-227

CA1575 MNHN-IU-

C. cf.

meridionalis

GUC467

2018-219

C.

coulaborensis

C.

coulaborensis

C.

coulaborensis

C.

coulaborensis

C. fritzi

C. fritzi
CA1726

MNHN-IU-

2018-217

CA1772 MNHN-IU-

2018-228

CA048 NMB 1057d 2

CA049 NMB 1057e

NMB 1057e Paratype

NMB 1057 e

CA050

2

CA051 NMB 1057e

NMB 1057e Paratype

3

CA052

NMB $1058 \mathrm{c}$

1

CA053 NMB 1058c

CA053 2

CA1610 $\begin{aligned} & \text { MNHN-IU } \\ & \text { 2018-222 }\end{aligned}$
MH497556 This study

MH497557 This study

MH497554 This study

MH497555 This study

MH497497 This study

MH497526 This study

MH497527 This study

MH497528 This study

DQ478492 Page et al. 2007

MH497544 This study

MH497545 This study

MH497491 This study

MH497492 This study

MH497493 This study

MH497494 This study

MH497495 This study

MH497496 This study

MH497529 This study

Table 2. Comparison of the egg size of different specimens of Caridina meridionalis

\begin{tabular}{lccc}
\hline Specimen & Altitude $(\mathrm{m})$ & Development stage & Size $(\mathrm{mm})$ \\
\hline NMB 1056b lectotype of $C$. meridionalis & 250 & Early stage & $0.57-0.60 \times 0.35-0.40$ \\
NMB 1061 g 4 & 11 & Early stage & $0.39-0.42 \times 0.26-0.29$ \\
CA1575 & 0 & Early stage & $0.46-0.50 \times 0.26-0.27$ \\
CA1576 & 0 & Early stage & $0.46-0.50 \times 0.27-0.29$ \\
CA1609 & 0 & Eyes visible & $0.45-0.49 \times 0.26-0.28$ \\
CA1610 & 0 & Early stage & $0.43-0.44 \times 0.26-0.27$ \\
CA1621 & 0 & Early stage & $0.35-0.40 \times 0.24-0.26$ \\
CA1725 & 4 & Eyes visible & $0.40-0.45 \times 0.24-0.26$ \\
NMB 1057a paratype of $C$. coulaborensis & 250 & Early stage & $0.66-0.76 \times 0.42-0.48$ \\
NMB 1057c 1 paratype of $C$. coulaborensis & 250 & Early stage & $0.72-0.76 \times 0.45-0.49$ \\
\hline
\end{tabular}

